NBER WORKING PAPER SERIES

\title{
US WATER POLLUTION REGULATION OVER THE LAST HALF CENTURY: BURNING WATERS TO CRYSTAL SPRINGS?
}

\author{
David A. Keiser \\ Joseph S. Shapiro \\ Working Paper 26077 \\ http://www.nber.org/papers/w26077 \\ NATIONAL BUREAU OF ECONOMIC RESEARCH \\ 1050 Massachusetts Avenue \\ Cambridge, MA 02138 \\ July 2019, Revised September 2019
}

We thank our discussant, Sheila Olmstead, and Pietro Bonetti, Steve Cicala, Michael Hanemann, Matt Kotchen, Christian Leuz, Giovanna Michelon, Katherine Wagner, and Reed Walker for excellent suggestions, seminar participants at NBER and UC Berkeley for useful comments, and Sam Goldman and Kenneth Lai for superb research assistance. For generous funding, Keiser thanks the United States Department of Agriculture through the National Institute of Food and Agriculture Hatch project number IOW03909, and Shapiro thanks National Science Foundation grants SES-1530494 and SES-1850790, the Alfred P. Sloan Foundation, and the Giannini Foundation. The views expressed herein are those of the authors and do not necessarily reflect the views of the National Bureau of Economic Research.

NBER working papers are circulated for discussion and comment purposes. They have not been peer-reviewed or been subject to the review by the NBER Board of Directors that accompanies official NBER publications.

(C) 2019 by David A. Keiser and Joseph S. Shapiro. All rights reserved. Short sections of text, not to exceed two paragraphs, may be quoted without explicit permission provided that full credit, including $(\odot)$ notice, is given to the source. 
US Water Pollution Regulation over the Last Half Century: Burning Waters to Crystal Springs? David A. Keiser and Joseph S. Shapiro

NBER Working Paper No. 26077

July 2019, Revised September 2019

JEL No. H23,K32,Q5

\begin{abstract}
In the half century since the founding of the U.S. Environmental Protection Agency, public and private U.S. sources have spent nearly $\$ 5$ trillion (\$2017) to provide clean rivers, lakes, and drinking water, or annual spending of 0.8 percent of U.S. GDP in most years. Yet over half of rivers and substantial shares of drinking water systems violate standards, and polls for decades have listed water pollution as Americans' number one environmental concern. We assess the history, effectiveness, and efficiency of the Clean Water Act and Safe Drinking Water Act, and obtain four main conclusions. First, water pollution has fallen since these laws, in part due to their interventions. Second, investments made under these laws could be more cost-effective. Third, most recent studies estimate benefits of cleaning up pollution in rivers and lakes which are less than their costs, though these studies may under-count several potentially important types of benefits. Analysis finds more positive net benefits of drinking water quality investments. Fourth, economic research and teaching on water pollution is relatively uncommon, as measured by samples of publications, conference presentations, and textbooks.
\end{abstract}

\author{
David A. Keiser \\ Iowa State University \\ 468F Heady Hall \\ Ames, IA 50011 \\ dkeiser@iastate.edu \\ Joseph S. Shapiro \\ University of California at Berkeley \\ 714 University Hall \#3310 \\ Berkeley, CA 94720 \\ and NBER \\ joseph.shapiro@berkeley.edu
}


In 1969, the Cuyahoga River in Cleveland, Ohio, lit on fire. Historically, this fire was unremarkable-rivers in Baltimore, Detroit, Buffalo, Philadelphia, and elsewhere caught fire throughout the $19^{\text {th }}$ and early $20^{\text {th }}$ centuries, and the Cuyahoga had lit on fire at least thirteen times since 1868 (Adler 2002). But the event attracted enormous attention. A widely read Time magazine (1969) article noted:

The Potomac reaches the nation's capital as a pleasant stream, and leaves it stinking from the 240 million gallons of wastes that are flushed into it daily. Among other horrors, while Omaha's meat packers fill the Missouri River with animal grease balls as big as oranges, St. Louis takes its drinking water from the muddy lower Missouri because the Mississippi is far filthier. ... Among the worst of them all is the 80-mile-long Cuyahoga ... No Visible Life. Some river! Chocolatebrown, oily, bubbling with subsurface gases, it oozes rather than flows. "Anyone who falls into the Cuyahoga does not drown,” Cleveland’s citizens joke grimly. "He decays.”

Outrage at the 1969 fire is often listed as one reason behind the passage of U.S. environmental laws in the early 1970s (Adler 2002; Dingell 2010).

The Cuyahoga has not burned since 1969 and today is the home to 40 species of fish (NPS 2018). But water pollution issues are not just a part of history. Today, over half of US rivers and lakes violate environmental standards, and 4 to 28 percent of Americans in a typical year receive drinking water from systems that violate health-based standards (Allaire et al. 2018; USEPA 2018a). Flint, Michigan, recently exposed 100,000 residents to dangerous levels of lead in drinking water. Contaminated drinking water leads an estimated 16 million Americans to suffer from gastrointestinal illness annually (Messner et al. 2006).

Polls also suggest that water pollution has been Americans’ top environmental concern for at least 30 years (Gallup 2018). Figure 1 shows the percentage of respondents to an annual U.S. Gallup poll who say they are concerned a "great deal” about various environmental problems. Sixty percent of Americans today list drinking water pollution and also river and lake pollution as a great concern. In every survey since 
1989, the share concerned about these issues has substantially exceeded the share expressing concern about air pollution, climate change, or other environmental problems (Gallup 2018).

The federal government sought to address these concerns with three actions-it created the Environmental Protection Agency in 1970, the Clean Water Act in 1972, and the Safe Drinking Water Act in 1974. The Clean Water Act regulates "surface waters"-rivers, lakes, and some ocean areas. Whether the Clean Water Act regulates groundwater, which includes subsurface aquifers, is legally disputed (Brownhill and Rosen 2018). The Safe Drinking Water Act regulates drinking water, which includes groundwater or surface water that is purified by a drinking water treatment plant and then transported by pipe to households and businesses.

A half century later, these laws still manage US surface and drinking water. Since 1970, the United States has spent approximately $\$ 4.8$ trillion (in 2017 dollars) to clean up surface water pollution and provide clean drinking water, or over $\$ 400$ annually for every American. ${ }^{2}$ In the average year, this accounts for 0.8 percent of GDP, making clean water arguably the most expensive environmental investment in US history. By comparison, the average American spends $\$ 60$ annually on bottled water (Arthur 2018).

This essay is structured around four main questions: What forces led to these laws? How do they regulate pollution? How effective and efficient have they been? Why has recent economic research focused relatively little on water pollution, and what can remedy this lack of research? ${ }^{3}$ We illustrate that water pollution provides an excellent setting to learn about externalities, cost-benefit analysis, local public goods, fiscal federalism, regulatory design, non-market valuation, and other classic economic issues. Indeed, water pollution is a textbook example of an externality—at least since Stigler (1952, 1966), introductory texts have used the example of a plant dumping waste in a river and causing people downstream to suffer to illustrate the concept of externalities.

\footnotetext{
${ }^{2}$ For the calculations behind this estimate, see Appendix A available with this paper at the JEP website.

${ }^{3}$ Other economic reviews of water pollution appear in Freeman (2000), Olmstead (2010), Griffiths et al. (2012), and Fisher-Vanden and Olmstead (2013).
} 
We emphasize four conclusions. First, many measures of drinking and surface water pollution have fallen since the EPA's founding, due at least in part to the Clean Water Act and Safe Drinking Water Act. The progress, however, is incomplete. William Ruckelshaus, first head of the Environmental Protection Agency, summarized: "Even if all of our waters are not swimmable or fishable, at least they are not flammable” (as quoted in Mehan 2010). Second, these large investments could be more cost-effectivethey could achieve the same aggregate pollution reduction at lower cost, by better utilizing market-based instruments, regulating agriculture, and exploiting returns to scale in drinking water treatment. Third, most analyses estimate that the benefits of existing regulations of surface water quality are less than their costs, which is not the case for most government regulations. We highlight several reasons why existing studies may under-estimate the true value of surface water quality. Fourth, relatively little economic research focuses on water pollution and its regulation, especially relative to research on air pollution. We discuss reasons for this lack of research.

\section{What Forces Led to the Clean Water Act and Safe Drinking Water Act?}

Human health provided the most common historic rationale for public policy to improve water quality. Sanskrit texts from 4,000 years ago describe purification methods for drinking water that are still used today. Even Roman bureaucrats under Augustus Caesar sought to eliminate lead piping since it was “hurtful to the human system” (Raucher 1996). For centuries, typhoid and cholera caused a large number of deaths. John Snow's (1855) famed study of London, which provided early evidence that water transmitted cholera, is sometimes considered the founding of modern epidemiology and quasi-experimental research. In the early $20^{\text {th }}$ century, many cities began chlorinating and filtering drinking water, and cholera and typhoid rates plummeted (Cutler and Miller 2005; Alsan and Goldin forthcoming). By the 1950s, these investments had nearly eliminated US cholera and typhoid epidemics, and so weakened the health-based rationale for additional investment. 
The federal government created some drinking water standards in the early $20^{\text {th }}$ century, but before the 1970s, the federal government had largely left water quality up to cities and states. Their water pollution policies and enforcement were limited: as of 1969, only 59 percent of drinking water systems met the preexisting federal standards (USPHS 1970). For surface waters, the federal laws before the Clean Water Act of 1972 also had limited power. A 1948 law included regulations that Congress described as "almost unenforceable,” and President Dwight Eisenhower called water pollution a "uniquely local blight.” Regulators summarized, "The solution to pollution is dilution” (Milazzo 2006). After one of the earlier Cuyahoga River fires, for example, Cleveland prohibited refineries from discharging oil into the Cuyahoga, but violation of this ordinance was only punished with a rarely applied \$10 fine (Adler 2002).

The environmental movement helped change this inattention to water pollution. Demonstrations for the first Earth Day in 1970 included 20 million people-among the largest demonstrations in US history. Along with the 1969 Cuyahoga River fire, other proximate causes of the environmental movement include the production of many new industrial chemicals, photographs of Earth taken from space, and a major 1969 oil spill off the coast of Santa Barbara, California. In 1973, a study found dozens of chemicals, including potential carcinogens, in the drinking water of New Orleans and Pittsburgh (Raucher 1996). New Orleans area residents at the time described drinking water supplies as smelling “oily-petrochemical,” and fish from the nearby Mississippi River as unsellable due to “oily” or “chemical” tastes (USEPA 1972; Agee 1975). Deeper causes of the environmental movement at this time may have included broader social activism and rising national incomes.

Several aspects of politics from the 1950s and 1960s affected water pollution policy in the 1972 Clean Water Act and beyond. First, discussions of surface water pollution had little reference to health; indeed, the Clean Water Act is perhaps the only major environmental regulation of the 1970s and 1980s which does not have health as a main goal (Cropper and Oates 1992). Second, because industry opposed regulation of water pollution, policymakers focused on subsidies to wastewater treatment plants rather than industrial regulation. Third, to assuage concerns that southern states were attracting manufacturing with weak regulation, policymakers created uniform national standards. Finally, to ensure political support from 
rural representatives, investment in reducing water pollution disproportionately targeted small towns (Milazzo 2006). Water quality policy at that time also largely ignored agriculture.

\section{How Do These Laws Regulate Pollution?}

\section{Clean Water Act}

The general goals of the 1972 Clean Water Act were implausibly ambitious: eliminating discharge of all pollutants into navigable waters by 1985; making all water safe for fishing and swimming by 1983; and prohibiting all discharge of toxic amounts of toxic pollutants. ${ }^{4}$ President Nixon vetoed the Clean Water Act, due to costs that he called "unconscionable" and "budget-wrecking," but bipartisan majorities voted to override the veto in the Senate (52-12, with 36 Senators not voting), and the House (247-23, with one “present” and 160 abstentions) (CQ Almanac 1972).

The Clean Water Act had two main activities. The first provided grants to cities to improve wastewater treatment plants. In most cities, underground pipes transmit polluted water from homes and businesses to a plant which abates pollution before discharging treated wastes to surface waters. The US has around 15,000 such plants. The federal government allocated grant funding across states based on formulas considering state population, forecast population, and wastewater treatment needs (CBO 1985). Within a state, grants were allocated based on an annual "priority list.” These grants began in 1957 under predecessor laws to the Clean Water Act, but their scale increased after 1972. In total, the federal government provided around 35,000 grants. Projects funded by these grants between 1960 and 2005 cost about $\$ 870$ billion over their lifetimes (in 2017 dollars)—about $\$ 230$ billion in federal grant funds, \$110 billion in municipal matching funds, and $\$ 530$ billion in operation and maintenance costs. ${ }^{5}$ In 1987 , the grants program transitioned to a subsidized loan program, the Clean Water State Revolving Fund.

\footnotetext{
${ }^{4}$ Technically the 1972 law was called the Federal Water Pollution Control Act Amendments of 1972. We follow common practice in referring to it as the Clean Water Act.

${ }^{5}$ For details, see the online Appendix A available with this paper at the journal's website.
} 
The Clean Water Act’s second main policy involved permits distributed to facilities discharging pollution from a fixed source (like a pipe) into navigable surface waters-the National Pollution Discharge Elimination System. Each permit describes the levels of pollution the plant may discharge. These permits focus on five conventional pollutants (for example, bacteria like fecal coliform) and 126 "priority" toxic pollutants, though may cover other water quality measures (USEPA 2010).

It may be informative to compare the Clean Water Act to other countries’ water quality policies. Many countries have subsidized municipal investment in wastewater treatment plants, including Brazil, Canada, France, India, Japan, New Zealand, and South Korea, and many countries set standards to regulate industrial pollution emissions. Other aspects of regulation, however, differ substantially between countries. Canada's 1970 Canada Water Act focuses on supporting partnerships between Canada's federal and provincial governments, on product standards, and on research; the U.S. Clean Water Act focuses on these less (Booth and Quinn 1995). The year 2000 EU Water Framework Directive has limited enforcement provisions but centralizes most regulatory decisions in the European Commission (whereas the Clean Water Act decentralizes many decisions to states) and regulates groundwater (Craig 2018). Agricultural runoff and non-point source pollution remain a top water quality problem in many industrialized countries, though farm management and training in some countries may help (Parris 2011).

The Clean Water Act's focus on wastewater treatment and point-source emissions has led to less focus on other water pollution concerns. Here, we mention several such issues.

The Clean Water Act largely ignores agricultural pollution, which contributes to some of the worst surface water quality problems (Craig and Roberts 2015). These problems include a "Dead Zone” in the Gulf of Mexico where oxygen shortages kill much aquatic life. The Clean Water Act does regulate large and some medium-sized animal feedlots (“concentrated animal feeding operations”). Initially, the Clean Water Act ignored agricultural pollution because it was not perceived as an important issue and because it was more difficult to monitor abatement and emissions. Agricultural water pollution abatement typically involves management practices, such as the timing and method of applying fertilizer and its relationship to soil conditions. Agricultural pollution abatement also involves land-use decisions, which the U.S. federal 
system general reserves as a power for states (Malik, Larson, and Ribaudo 1994). The federal government does operate some farm management programs pertinent to pollution, but these programs are voluntary and have low funding (Keiser, Shapiro, and Kling 2019).

Another challenge involves the language of the Clean Water Act protecting "Waters of the United States,” which has led to legal debates over how this term applies to roughly half of US waters, primarily comprised of wetlands, headwaters, and intermittent streams. Two Supreme Court decisions hold that the Clean Water Act does not protect most of these waters (Rapanos v. United States, 547 US 715 [2006]; Solid Waste Agency of Northern Cook County (SWANCC) v. U.S. Army Corps of Engineers, 531 US 159 [2001]). In 2015, the Obama administration issued the Waters of the United States Rule, which sought to reinstate these protections. However, in 2017 President Trump issued an executive order to rescind or revise this rule. The net benefits of these regulations have also become controversial (Boyle, Kotchen, and Smith 2017).

An additional challenge is the rise of fracking (more properly, hydraulic fracturing), which has increased US gas and oil production, but has also raised concerns of contaminating ground and surface waters. Fracking extracts natural gas or crude oil from underground shale rock, typically by combining horizontal drilling with the high-pressure injection of water, chemicals, and sand. The corresponding concerns for water quality involve chemicals leaking from wells, improper cement casing around the well, or improper storage of fracking liquids in surface ponds (Olmstead et al. 2013; Mason, Muehlenbachs, and Olmstead 2015). The 2005 Energy Policy Act exempted fracking from a portion of the Safe Drinking Water Act which regulates underground injection of contaminants, but fracking remains subject to the Clean Water Act.

A short list of additional challenges involving the Clean Water Act includes "combined sewer systems” that dump raw sewage in rivers during heavy storms (primarily in small cities in the Northeast and industrial midwest); power plants forced by NPDES permits to shutoff on hot days; the Clean Water Act focuses on few pollutants, whereas U.S. industry manufactures, processes, or imports 33,000 chemical substances (USEPA 2019); air pollution abatement technologies that convert air pollution to surface water 
pollution; total maximum daily load requirements, a regulatory tool with 75,000 local pollution budgets promulgated since 1995 (USEPA 2018a); and the limited prevalence of cap-and-trade markets for water quality (as discussed in this journal by Fisher-Vanden and Olmstead 2013).

\section{Safe Drinking Water Act}

Broadly, the Safe Drinking Water Act seeks to protect health by limiting drinking water contamination. The law was also popular at its passage - it passed with a voice vote in the Senate and 29684 in the House (CQ Almanac 1974).

The Safe Drinking Water Act includes three main policy instruments. First, it provides a process for setting and enforcing drinking water standards. The EPA sets an enforceable "maximum contaminant level” for 94 contaminants, including microorganisms like E. Coli; radionuclides like uranium; organic chemicals like glyphosate (a weed-killer); inorganic chemicals like cyanide; and disinfectants like chlorine and their byproducts (USEPA 2015, 2018b). States can regulate additional contaminants beyond the 94. For example, California but not the EPA enforces standards on perchlorate, a component of rocket fuel (California Water Boards 2018). The EPA also sets non-enforceable "secondary standards" when contaminants create issues involving taste, color, and smell, which have primarily aesthetic importance. While the EPA designs standards, states enforce them, typically using administrative orders, modest civil penalties, or prison, and enforcement is incomplete (Tiemann 2007). A water system can violate these standards by exceeding contaminant limits, by failing to treat water appropriately, or by failing to report tests (USEPA 1999).

Second, the Safe Drinking Water Act authorizes actions to protect groundwater from contamination. This includes regulations of wells drilled for underground fluids (the Underground Injection Control Program); designation of some aquifers as primary drinking water sources, which then prevents any federal funds for purposes that could contaminate these aquifers (the Sole Source Aquifer Program); and protection of areas around groundwater wellheads (the Wellhead Protection Program). 
The third main activity involves subsidies for cleaner drinking water. Some subsidies fund drinking water treatment, distribution networks, and related infrastructure, and others provide grants for data management.

The Safe Drinking Water Act regulates roughly 150,000 public and private water systems. About 50,000 of these ("community water systems") provide water to standard homes; the others supply water to sites like schools, factories, campgrounds, and others. The largest 400 community water systems cover nearly half the US population, while the smallest 28,000 systems cover only 2 percent of the population (Tiemann 2017). The law does not regulate domestic wells, which serve about 45 million Americans, or bottled water, which the Food and Drug Administration regulates.

Fiscal federalism provides an interesting comparison between the Clean Water Act and Safe Drinking Water Act. Because rivers flow between states, they provide a classic example of an interjurisdictional externality. Perhaps for this reason, the Clean Water Act provided federal subsidies for wastewater treatment. Drinking water treatment, by contrast, creates less externality between cities and jurisdictions, and accordingly, the Safe Drinking Water Act provides less federal funding.

Like the Clean Water Act, the Safe Drinking Water Act also faces some ongoing challenges and issues. Here, we briefly describe four of them.

First, the Safe Drinking Water Act regulates 94 contaminants; many unregulated chemicals are believed to be toxic and are found in drinking water, including some pesticides and pharmaceuticals. No new contaminants have been regulated since 2006 (Sullivan, Agardy, and Clark 2005; USEPA 2015; USEPA 2018b). Concern about toxic chemicals in drinking water is longstanding and has been magnified at times by popular media, going back to Rachel Carson’s 1961 book Silent Spring and movies like “A Civil Action” (1998) and “Erin Brockovich” (2000). One contaminant common in drinking water, but not currently regulated, is per- and polyfluoroalkyl substances (PFASs), used to repel water and oil. These chemicals appear in non-stick cookware and pizza boxes, and some evidence links them to cancer and infant health problems (ATSDR 2019). 
Second, lead is a toxic metal which retards brain development. It typically appears in drinking water due to plumbing materials that contain lead, including pipes or soldering. The Safe Drinking Water Act has used increasingly stringent provisions to remove lead from drinking water systems. Recent crises in Flint, Michigan, and elsewhere underscore its continuing challenge (SciLine 2019).

Third, some are concerned that fracking has allowed chemicals to penetrate groundwater, which then feeds into drinking water. Evidence on the prevalence of such pollution is mixed, though households appear willing to pay reasonable sums to avoid such potential contamination (Mason, Muehlenbachs, and Olmstead 2015; Muehlenbachs, Spiller, and Timmins 2015; Wrenn, Klaiber, and Jaenicke 2016).

Fourth, many abatement technologies have increasing returns to scale (Olmstead 2010). Water quality regulations are weaker for small or intermittent drinking water systems and nonexistent for rural wells.

\section{How Effective Have These Laws Been?}

The extent to which the Clean Water Act and Safe Drinking Water Act affect water pollution depends on how these laws alter enforcement and compliance behavior. For example, to what extent do standards require actual changes? To what extent do regulators test water, and then notify and punish violators? On the compliance side, what is the cost to decrease pollution? These compliance costs evolve based on developments in abatement technologies, which can decrease through learning by doing, economies of scale, or innovation. Additionally, compliance depends on the ability of sources to circumvent these laws—for example, by relocating emissions or reclassifying economic activity.

Existing research does not speak to all of these individual channels of enforcement and compliance, but does indicate aggregate changes in pollution. Surface water treatment has improved substantially since the early 1970s. In 1940, municipal wastewater treatment plants removed about 20 percent of a common measure of pollution (“biochemical oxygen demand”), and by 1996, they removed nearly 70 percent of it (USEPA 2000b). Industrial treatment has also expanded. In 1954, only 13 percent of water used in large 
US manufacturing plants had any treatment before discharge; by 1982, 30 percent did (U.S. Census 1971, 1986). ${ }^{6}$

Several studies find evidence of decreased surface water pollution. Some use small sets of monitoring sites (Smith, Alexander, and Wolman 1987, USEPA 2000b), though one finds no change for dissolved oxygen in a large sample of lakes (Smith and Wolloh 2012). A national water quality simulation model also suggests substantial decreases in ambient pollution due to observed changes in emissions (Bingham et al. 2000). More comprehensive evidence comes from 50 million pollution readings from 240,000 monitoring sites (Keiser and Shapiro 2019). That analysis finds that most pollutants have declined substantially, though agricultural pollutants like nitrates have not. It also finds that the rate of decrease for most pollutants has slowed over time.

Figure 2 shows an example of this evidence of the substantial decrease in U.S. surface water pollution. This graph summarizes 14.6 million pollution readings covering 265,000 monitoring sites over the period 1972-2014. This graph shows a common omnibus measure of water quality—whether waters are safe for fishing. This definition of "fishable" is widely used in research; it was developed by William Vaughan for Resources for the Future and reflects published water quality criteria and state water quality standards between 1966 and 1979. When the Clean Water Act passed in 1972, nearly 30 percent of water quality readings were unsafe for fishing. This share has trended steadily downward, and by 2014, only about 15 percent were. ${ }^{7}$ Such decreases could in principle arise from outsourcing dirty production, productivity growth, environmental lawsuits, or environmental regulation (Shapiro and Walker 2018).

Some studies estimate how much of the change in water pollution can be attributed to the Clean Water Act. Keiser and Shapiro (2019) use a triple-difference research design comparing areas upstream versus downstream of wastewater treatment plants and before versus after plants receive grants and across

\footnotetext{
${ }^{6}$ The Survey of Water Use in Manufacturing, which provided these industrial data, was discontinued after the 1980s, though the U.S. Census Bureau has recently discussed starting it again.

${ }^{7}$ Appendix Figure 1, available with this paper at the journal's website, shows similar patterns for the four physical pollutants underlying this measure of whether waters are fishable. For the period 1962-2001, Appendix Table III of Keiser and Shapiro (2019) shows similar trends in many sensitivity analyses.
} 
many plants. They find that Clean Water Act grants significantly decrease pollution for 25 miles downstream and for 30 years. Inspections and fines are generally implemented through the National Pollution Discharge Elimination System. Studies exploiting variation in inspections and fines over space and time find that they decrease pollution from wastewater treatment plants and pulp and paper manufacturing (Magat and Viscusi 1990; Laplante and Rilstone 1996; Helland 1998; Earnhart 2004; Glicksman and Earnhart 2007; Gray and Shimshack 2011). For example, Shimshack and Ward (2008) use differences-in-differences regressions for about 250 paper mills in 28 states over 14 years to find that fines on a plant, or on another plant in the same state, are associated with decreases in reported emissions of two common pollutants.

Evidence on trends in drinking water quality and treatment is less clear. Some evidence suggests that drinking water quality has improved, but unfortunately the best long-term national data record violations of standards rather than actual pollution concentrations, which is more complex to interpret because standards change frequently. The share of community water systems which treat water at all grew substantially between the 1970s and 1990s (USEPA 1999). In 1969, 40 percent of systems violated standards, while in 2015, only 10 percent did, even as standards tightened (US PHS 1970; Allaire, Wu, and Lall 2018). ${ }^{8}$ Figure 3 shows this pattern over the period 1982-2015. This graph shows that violations jump discretely each time the Safe Water Drinking Act incorporates tighter standards, and then the frequency of violations gradually declines as water systems become more likely to comply with the new rule (Allaire, Wu, and Lall 2018).

Some research directly analyzes the effects of the Safe Water Drinking Act and its subsequent amendments. Bennear and Olmstead (2008) exploit variation over time and across drinking water systems to find that the legal requirement for some systems to send annual water quality reports to customers decreased total and health-based water quality violations by more than one-third. Grooms (2016) shows that mean quarterly arsenic concentrations in Californian drinking water follow a linear trend through the

\footnotetext{
${ }^{8}$ These 1969 and 2015 statistics are not perfectly comparable—each takes a non-random sample of drinking water systems, and they focus on different measures of violations.
} 
early 2000s, then fell by 50 percent in exactly the fourth quarter of 2008, when arsenic standards were tightened. This analysis does not have a control group, though does find an abrupt change in a time-series. Nigra et al. (2017) show that urinary arsenic concentrations in a national sample of 14,000 Americans had similar trends before the year 2008 for Americans that drank water from public systems versus for Americans that drank well water. After 2008, arsenic concentrations fell for individuals using public water systems after 2008 but did not change for individuals drinking well water, which did not face new regulations.

\section{How Efficient Has Regulation of Clean Water Been?}

The analysis of gains or losses to social welfare from policies to reduce water pollution often involves assessment of three elements: the consumer surplus that people obtain from any decreases in pollution resulting from these policies (including gains due to health, recreation, and other channels), the lost producer surplus from firms due to complying with these regulations; and deadweight loss from taxation to raise revenue for pollution abatement subsidies.

Research has used various methods to investigate these questions. To measure the benefits of cleaner water, some studies use the "travel cost" method, based on changes in where people travel for boating, fishing, or swimming. Others use hedonic methods to analyze changes in home values, look at investments in defensive goods like bottled water, or study health consequences. Still others use “stated preference” methods, which include contingent valuation surveys, but have been controversial (as discussed in this journal by Diamond and Hausman 1994; Hausman 2012; Kling, Phaneuf, and Zhao 2012). Health-based methods are the most common approach for estimating the value of drinking water quality. To measure the costs of providing clean water, some studies use accounting data from surveys of firm expenditures on pollution abatement; others use engineering estimates of the costs of abatement technology; and still others use reported government accounts. 
Table 1, Panel A, shows estimates of the total cost of cleaning up surface water pollution, providing clean drinking water, and abating air pollution. Appendix A describes how we construct these cost estimates in detail, but here we summarize. For federal expenditures, we use microdata from a federal accounting database, the Grants Information and Control System, and from annual reports of the Clean Water State Revolving Fund. For state and local expenditures, we use summaries from the Annual Survey of Governments and Annual Census of Governments. For industrial expenditures, we primarily use data from a survey of manufacturing plants, the Pollution Abatement Costs and Expenditures Survey.

Over the period 1970 to 2014, we calculate total spending of \$2.8 trillion to clean up surface water pollution, \$2.0 trillion to provide clean drinking water, and \$2.1 trillion to clean up air pollution (all converted to 2017 dollars). Total spending to clean up water pollution exceeded total spending to clean air pollution by 70 to 130 percent.

Figure 4 shows these spending patterns by year. Between 1973 and 1987, annual spending to clean up surface waters was only slightly higher than spending to clean up air pollution, at $\$ 40$ to $\$ 63$ billion per year. Spending on drinking water treatment was lower, at \$17 to \$37 billion per year. Since 1987, spending to treat surface and drinking waters has steadily increased, which might reflect regulation of more toxic pollutants or maintenance of aging infrastructure.

Table 1, Panel B, summarizes benefit-cost analyses of 240 regulations the federal government implemented over the period 1992-2017. For years after 2004, data are from Table A-1 of the annual "Report to Congress on the Benefits and Costs of Federal Regulations and Unfunded Mandates on State, Local, and Tribal Entities,” which is published by the Office of Information and Regulatory Affairs within the White House Office of Management and Budget. For earlier years, data are from various tables of predecessor reports. For many years, the federal government has completed a prospective evaluation (technically, a “Regulatory Impact Analysis”) for all major regulations. This evaluation typically estimates all quantifiable benefits and costs, where possible in monetary terms. The regulation may be implemented regardless of the result, though regulations with unfavorable benefit/cost ratios are more scrutinized. In 
other work, we have reviewed studies by academics, which have similar patterns (Keiser, Kling, and Shapiro 2019).

For concreteness, we describe one of the studies for surface water summarized in Table 1. In 2004, the EPA considered requiring the meat and poultry products industry to decrease its water pollution emissions. ${ }^{9}$ To evaluate this regulation, the EPA and its contractor Eastern Research Group completed a 1,200-page “Development Document” and a 250-page “Economic and Environmental Analysis.” The analysis explains that this regulation would require plants to install abatement technologies like biological treatment, nitrification, or disinfection. Based on a 350-firm survey and on the 1997 Economic Census, the analysis estimates that this would cost $\$ 42$ to $\$ 58$ million annually. The analysis also estimates that this regulation would decrease emissions of nitrogen from this industry by 60 percent, sediment by 30 percent, and pathogens like E. coli by 80 percent. Using a national water quality simulation model (the National Water Pollution Control Assessment Model), the analysis estimates how these decreases in emissions would affect a water quality index from McClelland (1974), and then uses stated preference estimates from Carson and Mitchell (1993) to calculate households' associated willingness to pay. The analysis finds that the decreased pollution emissions would lead to benefits of $\$ 2.6$ million annually, with a range of $\$ 0$ to $\$ 10$ million (all figures in 2003 dollars). Given these estimated costs and benefits, this study implies an unfavorable estimated benefit/cost ratio of 0.052 (i.e., the estimated benefits are about five percent of the estimated costs), with a range of 0.0 to 0.24 . The EPA finalized the analysis in February 2004, published the final rule in the federal register in September 2004, and the regulation took effect in October 2004.

Table 1 distinguishes five categories of regulations: surface water; drinking water; air pollution; greenhouse gases; and all other (including non-environmental). It shows that four of these five categories of investments pass a benefit-cost test overall. For example, estimated total benefits from air pollution regulations exceed their estimated total costs by a factor of 12 . For drinking water studies, total benefits are

\footnotetext{
${ }^{9}$ Technically, this was a revision to the industry's Clean Water Act effluent guidelines. This rule finalized the first standards for poultry slaughterers or processors, and revised standards for other meat product plants. See https://www.epa.gov/sites/production/files/2015-11/documents/meat-poultry-products_eeba_2004.pdf (visited 7/2/2019).
} 
estimated to exceed total costs by a factor of 5. These are analyses of tightening existing regulation; the net benefits of maintaining existing drinking water treatment may be even greater, since basic drinking water treatment first got rid of typhoid and cholera. Surface water quality (including the meat and poultry regulation described in the previous paragraph) is the only one of these five categories of investment which fails a benefit-cost test—estimated total benefits are only 80 percent of estimated total costs. The next row in Table 1 describes the mean regulation—again all categories have a favorable benefit/cost ratio except surface waters, where the mean regulation has benefits that are 57 percent of its costs. The last row of Table 1 describes the share of regulations which are estimated to have benefits smaller than their costs. For surface water regulations, 67 percent of regulations fail a benefit-cost test; for drinking water regulations, only 20 percent do, and for air pollution regulations, only 8 percent do. Other studies using other samples of regulations reach a similar conclusions that many regulations to reduce surface water pollution fail a benefit-cost test, while most other regulations to reduce pollution pass such a test (Hahn 2000; Keiser, Kling, and Shapiro 2018).

Have investments to clean up U.S. surface waters actually led to negative net benefits, or is existing research underestimating their benefits? Benefit estimates from existing studies may be biased downward for several reasons; investigation of these channels would be valuable for future research (Keiser and Shapiro 2019; Keiser, Kling, and Shapiro 2019). Many studies focus on recreation, amenity, or other types of "use” values that people derive from visiting surface waters. Other, “nonuse” or "existence” values for clean water may also be important, though are difficult to measure well. For example, some people may be willing to pay to decrease pollution in iconic waters like the Great Lakes, Mississippi River, or San Francisco Bay, even if they never visit these water bodies. One assessment of the Clean Water Act did estimate that nonuse values are only a sixth as large as use values (USEPA 2000a), but the standard difficulties in measuring nonuse and existence values apply equally well to this analysis.

Other potential benefits are also hard to measure and potentially understated in existing analyses. Many studies ignore health benefits, by assuming that drinking water treatment plants purify any pollution in rivers and lakes before that water reaches households for drinking. For example, in prevailing analyses, 
health accounts for little to none of the benefits of the Clean Water Act, but most benefits of the Clean Air Act (Keiser, Kling, and Shapiro 2019). Many studies also use restrictive models of pollution transport, even though advances in hydrological routing models could allow more sophisticated analyses of pollution flows. Existing estimates abstract from changes in wages, which are one form in which improvements in marketlevel amenities like water quality can be capitalized (Roback 1982); they may also overlook changes in the equilibrium relationship of home prices to water pollution, which is another general equilibrium channel (Banzhaf 2018). More broadly, general equilibrium analyses of water pollution policy are limited. Existing estimates also abstract from benefits of reducing toxic and other non-conventional pollutants. Additionally, prevailing estimates generally assume that people have complete information about water pollution. While some newspapers print daily air pollution levels, anything close to this level of information is hard to obtain for water pollution. Furthermore, existing estimates abstract from ecological consequences like loss of biodiversity, and may miss benefits that accrue through groundwater and oceans.

Of course, existing studies may also inaccurately measure costs; the sign of this bias is ambiguous. Abatement costs represent market prices rather than surplus, abstract from market power and any associated loss to customers, ignore potentially valuable byproducts from abatement, can be difficult to distinguish from production or safety costs, can lead to learning-by-doing or innovation that decreases future abatement costs, and can increase the cost of consumer goods and thereby exacerbate distortions due to labor and capital taxes (Cremeans and Segal 1975; Bovenberg and Goulder 1996; Keiser, Kling, and Shapiro 2019).

One could diagnose inaccuracies of estimated benefits and costs for many types of regulation. Are net benefits are more severely underestimated for surface water quality than for other goods? Our subjective perception is that cost estimates for water and other types of regulations have similar quality. For benefits, the channels where environmental goods typically generate especially large benefits are either assumed for water to be nonexistent (health) or are hard to measure (non-use or existence values) (Olmstead 2010). Most existing benefits of surface water quality are believed to come from recreation, but available data on recreation is often geographically limited (e.g., one county, state, or lake) and often comes from a single 
cross-section. Hence, our subjective perception is that underestimation of benefits is more likely a concern for surface water quality regulation than for other regulations.

Even if current estimates understate the true benefits of investments in surface water quality, several reasons suggest why current and past regulation of surface water quality could produce smaller net benefits than other types of environmental investments (Keiser and Shapiro 2019). Surface water quality policy does not typically use market-based instruments like cap-and-trade markets, pollution taxes, or hybrids of these two (e.g., a cap-and-trade market with a price floor). Such policies are generally cost effective-they minimize the cost of pollution abatement. Fisher-Vanden and Olmstead (2013) identified 21 active and pilot programs; the Chesapeake Bay Watershed Nutrient Credit Exchange and Minnesota River Basin Trading market are two examples of recently-created markets. Of course, one reason for their rarity is the concern that they could create local areas of high pollution ("hot spots"); another reason is that some watersheds have few polluters, and thin markets could lead to higher transaction costs. Another inefficiency is that current policy ignores much of agriculture, which can make aggregate abatement more costly since current policy does not equate marginal abatement costs across all sources. Additionally, subsidizing abatement capital, which is primarily how the federal government addresses municipal wastewater treatment, can encourage too much investment in capital rather than in other factors of production like labor. Apart from specific policy choices, surface waters may be more substitutable than other environmental goods - changing the river where a person goes fishing or boating may be less costly than changing the air a person breathes (e.g., where the person lives or works) or the water a person drinks. Firms, which account for most air pollution abatement, may also find more cost-effective ways to abate water pollution than governments, which account for a large share of water pollution abatement.

Failing a cost-benefit test does not imply the U.S. should not invest in surface water quality. Apart from the fact that these analyses may underestimate true benefits, they also reflect the policy instruments and investments actually made. Using more cost-effective instruments, targeting investments to areas with greatest net benefits, and other reforms can achieve greater benefits for the same cost. Policymakers may also value other objectives, like equity. 
What is known about the efficiency of water pollution regulation elsewhere? Analysis of the EU's main water quality policy, the Water Framework Directive, is too preliminary to be meaningful. The main benefit-cost analysis the EU's main commissioned report summarizes is for a single watershed in Bulgaria (Russi and Farmer 2018, p. 53). Some evidence finds that India’s National River Conservation Plan has not significantly decreased water pollution (Greenstone and Hanna 2014). Exploiting local discontinuities in regulation, He, Wang, and Zhang (2018) find that reducing China's emissions of chemical oxygen demand (COD), an omnibus measure of industrial pollution, by 10 percent would cost US\$160 billion. They do not compare these costs to the associated benefits, though river pollution in China does appear to increase cancer mortality (Ebenstein 2012).

\section{Why a Dearth of Economic Research on Water Pollution?}

Given the importance of water quality and the strikingly low estimated benefit/cost ratios, surprisingly little economic research analyzes it. Table 2 describes several measures of research. Publications are perhaps the most relevant measure. Two to three times more JSTOR economics articles focus on the Clean Air Act than the Clean Water Act or Safe Drinking Water Act. In the top five economics journals, 45 articles discuss the Clean Air Act but only 2 discuss the Clean Water Act or the Safe Drinking Water Act. Even in environmental and energy economics journals, more than twice as many papers discuss the Clean Air Act than the Clean Water Act or Safe Drinking Water Act. At NBER Summer Institute sessions on energy and environmental economics (EEE) over the years 2009-2018, 21 papers discussed the Clean Air Act and only 3 discussed the Clean Water Act or Safe Drinking Water Act. We also reviewed eight leading graduate and undergraduate environmental economics textbooks. The mean book spent 3 times more pages discussing the Clean Air Act than the Clean Water Act. We also reviewed two undergraduate textbooks in public finance; they spent 3-6 pages discussing the Clean Air Act but did not discuss the Clean Water Act. Appendix Table 1 shows that relatively more papers mention water pollution 
than water pollution regulation. The Appendix Table 1 measures are less informative, however, since many of these papers focus on unrelated topics (e.g., crime) but mention the phrase "water pollution” once.

Discussing why relatively little economic research has focused on water pollution and its regulation may help explain these surprising patterns and also provide a road map for scholars seeking to start working in this area. One challenge is the limited availability of data on surface or drinking water pollution. The Environmental Protection Agency does not operate a comprehensive national monitoring network for water pollution. Many air pollution monitors report values hourly, while the average water pollution monitoring site in one large dataset reports every four months (Keiser and Shapiro 2019). Because many organizations collect water pollution data, using a range of methods and devices, it can be complex to determine which water quality data are accurate, representative, and comparable. Keiser and Shapiro (2019, Appendix B.3) describe several methods to address these issues.

One improvement in access to surface water quality data is the Water Quality Portal (http://www.waterqualitydata.us). Fully introduced in June 2018, it streamlines access to a broad range of water quality data. The portal covers about 300 million water quality records, 2.4 million monitoring sites, and 450 monitoring organizations (Read et al. 2017). It excludes the largest and oldest federal data repository, USEPA’s “STORET” (the STOrage and RETrieval) Legacy system, which includes 200 million water samples from 700,000 monitoring sites over roughly the years 1900-1998. STORET Legacy is more difficult to parse, though EPA plans eventually to incorporate it into the Water Quality Portal. Remote sensing (satellite) measures of water color and clarity are also becoming more common (Lee et al. 2014), as are automatic water quality monitors that can frequently detect and automatically report ambient levels (Anvari et al. 2009). While remote sensing is becoming influential in air pollution research, its use in water pollution research in economics is nascent. For groundwater, one smaller repository, the National GroundWater Monitoring Network, measures water quality in about 2,000 wells.

For data on drinking water quality, the most comprehensive source is the Tap Water Database, compiled by a nonprofit, the Environmental Working Group. Since 2010, this database has collected data from states. The Environmental Protection also maintains several records. The Safe Drinking Water 
Information System (SWDIS) begins earlier than the Tap Water Database but only reports violations and not pollution concentrations. The Annual Water Quality Reports is a database of annual reports that water utilities send consumers. Finally, the National Occurrence Database maintains some records of regulated and unregulated water contaminants.

A third challenge for water pollution research involves assessing where and when steps to reduce water pollution have taken place. Some recent progress in data availability may help. The Clean Watershed Needs Survey provides a panel census of the roughly 15,000 wastewater treatment plants that receive household and some business waste in most US cities. The Grants Information and Control System (GICS) provides data on over 35,000 grants the federal government gave cities through the Clean Water Act to improve wastewater treatment. The Environmental Protection Agency keeps records of inspections and enforcement actions against violators of the Clean Water Act-these data were formerly known as the Permit Compliance System, and a newer improved version is the Integrated Compliance Information System (ICIS) system. The Pollution Abatement Costs and Expenditures survey for many years collected information on firms' capital and operating costs to address pollution emissions. Many of these datasets have existed for decades, though have gradually become more accessible.

A fourth challenge involves causal inference. Because water quality regulation is somewhat uniform across space, it has been difficult for economists to identify effects of regulation by comparing regulated against unregulated areas. This concern is arguably less pronounced for other environmental goods.

A fifth challenge involves spatial computation. For studying air pollution and climate change, geographic aggregates like counties or states provide a reasonable unit of analysis. For water pollution, looking at spatial patterns determined by geography_like upstream and downstream on an individual river segment — can be informative. A few advances have made this form of analysis more feasible. The National Hydrography Dataset provides a georeferenced atlas of every US water feature. Software and computing advances like ArcGIS, QGIS, C++, and the National Hydrography Dataset have streamflow algorithms, and several papers now exploit the direction of streamflow (Ebenstein 2012; Olmstead et al. 2013; Cicala 
2017; Lipscomb and Mobarak 2017; Garg et al. 2018; Keiser and Shapiro 2019). Also, since 2000, the Watershed Boundary Database has a more spatially detailed watershed called a Hydrologic Unit Code. The most detailed, 12-digit HUCs, distinguish 100,000 separate local water areas (USDA 2018).

A sixth challenge is the choice of which water pollutants should be the main focus. The surface water pollution repositories discussed earlier describe over 16,000 different measures of pollution, and it is unclear how to choose a few measures that matters most. Some studies focus on one or a few omnibus measures of water pollution, though the chosen measure varies by study. For example, Sigman (2002) and Lipscomb and Mobarak (2018) use biochemical oxygen demand; Duflo et al. (2013) use biochemical oxygen demand, chemical oxygen demand, and a few others; and Keiser and Shapiro (2019) focus on whether waters are safe for fishing and on "dissolved oxygen," which measures the capacity of water to support aquatic life.

\section{Conclusion}

In 1970, the United States created the Environmental Protection Agency, then passed two sweeping laws designed to improve water quality - the Clean Water Act and the Safe Drinking Water Act. The resulting investments in cleaner water have not been cheap, costing on average about 0.8 percent of U.S. GDP per year. A half century later, many measures of drinking and surface water quality have improved, in part because of these laws. Industrial, sewage, and drinking water pollution have all decreased, though agricultural water pollution remains prevalent.

The investments in drinking water appear to create substantial health benefits which exceed their estimated costs. Perhaps surprisingly, however, existing evidence suggests that estimated costs of most investments in cleaning up rivers, lakes, and oceans exceed their measured benefits. Many of these estimates note that they have difficulty quantifying several important channels of benefits, and may be understating true benefits. Unfortunately, economic research on water pollution and its regulation has been 
limited. An important task for research is to assess which investments in surface water pollution create net benefits, along with ways to make these investments more effective. 


\section{References}

Adler, Jonathan H. 2002. "Fables of the Cuyahoga: Reconstructing a History of Environmental Protection.” Fordham Environmental Law Journal 89(14): 89-146.

Agee, James L. 1975. “Protecting America’s Drinking Water: Our Responsibilities Under the Safe Drinking Water Act.” EPA Journal 1(3): 2-5

Allaire, Maura. 2018. "Health-Based Violations of the Safe Drinking Water Act, 1982-2015.” https://doi.org/10.7910/DVN/IFV6SQ, Harvard Dataverse, V1. Visited 12/9/2018.

Allaire, Maura, Haowei Wu, and Upmanu Lall. 2018. "National trends in drinking water quality violations.” Proceedings of the National Academy of Sciences 115(9): 2078-2083.

Alsan, Marcella, and Claudia Goldin. Forthcoming. "Watersheds in Child Mortality: The Roles of Effective Water and Sewerage Infrastructure.” Journal of Political Economy.

Anderson, Terry L., and Gary D. Libecap. 2014. Environmental Markets: A Property Rights Approach. New York: Cambridge University Press.

Anvari, Alex, Jenny Delos Reyes, Ehsan Esmaeilzadeh, Ali Jarvandi, Nicholas Langley, and Keyssi Rivera Navia. 2009. “Designing an Automated Water Quality Monitoring System for West and Rhode Rivers.” Proceedings of the 2009 IEEE Systems and Information Engineering Design Symposium, University of Virginia, Charlottesville, VA, USA, April 24, 2009.

Arthur, Rachel. 2018. “'Bottled water is America’s favorite drink!’ Bottled water takes top spot in US.” Beverage Daily, June 1.

ATSDR. 2019. “Per- and Polyfluoroalkyl Substances (FAS) and Your Health. Agency for Toxic Substances and Disease Registry. https://www.atsdr.cdc.gov/pfas/health-effects.html. Visited 6/12/2019.

Banzhaf, H. Spencer. 2018. “Differences-in-Differences Hedonics.” Mimeo, Georgia State University.

Bennear, Lori S., and Sheila M. Olmstead. 2009. “The impacts of the 'right to know': Information disclosure and the violation of drinking water standards.” Journal of Environmental Economics and Management 56(2): 117-130. 
Berck, Peter, and Gloria Helfand. 2011. The Economics of the Environment. Boston, MA: AddisonWesley.

Bingham, Tayler H., Timothy R. Bondelid, Brooks M. Depro, Ruth C. Vigueroa, A. Brett Hauber, Suzanne J. Unger, and George L. Houtven. 2000. “A Benefits Assessment of Water Pollution Control Programs Since 1972: Part 1, The Benefits of Point Source Controls for Conventional Pollutants in Rivers and Streams.” Technical Report, RTI.

Booth, Larry, and Frank Quinn. 1995. "Twenty-Five Years of the Canada Water Act.” Canadian Water Resources Journal 20(2): 65-90.

Bovenberg, A. Lans, and Lawrence H. Goulder. 1996. “Optimal Environmental Taxation in the Presence of Other Taxes: General-Equilibrium Analyses.” American Economic Review 86(4): 985-1000.

Boyle, Kevin J., Matthew J. Kotchen, and V. Kerry Smith. 2017. "Deciphering dueling analyses of clean water regulations.” Science 358(6359): 49-50.

Brownhill, Stacy L., and Julie A. Rosen. 2018. “Clean Water Act Groundwater Pollution Liability in Limbo.” National Law Review October 4.

California Water Boards. 2018. “Contaminants in Drinking Water.” https://www.waterboards.ca.gov/drinking_water/certlic/drinkingwater/Chemicalcontaminants.htm $\underline{1}$ Visited 6/30/2019.

Callan, Scott J., and Janet M. Thomas. 2013. Environmental Economics \& Management: Theory, Policy, and Applications. Mason, OH: South-Western.

Carson, Richard T., and Robert Cameron Mitchell. 1993. “The Value of clean water: The public's willingness to pay for boatable, fishable, and swimmable quality water.” Water Resources Research 29(7): 2445-2454.

CBO. 1985. "Efficient investment in wastewater treatment plants.” Technical report, Congressional Budget Office.

Chapman, Duane, 2000. Environmental Economics: Theory, Application, and Policy. Reading, MA: Addison-Wesley. 
Cicala, Steve. 2017. "Imperfect Markets Versus Imperfect Regulation in U.S. Electricity Generation.” NBER Working Paper 23053.

CQ Almanac. 1972. “Clean Water: Congress Overrides Presidential Veto.” Visited 12/5/2018. https://library.cqpress.com/cqalmanac/document.php?id=cqal72-1249049

CQ Almanac. 1974. “Safe Drinking Water.” Visited 12/5/2018. https://library.cqpress.com/cqalmanac/document.php?id=cqal74-1225339

Craig, Robin Kundis, and Anna M. Roberts. 2015. "When Will Governments Regulate Nonpoint Source Pollution? A Comparative Perspective.” Environmental Affairs Law Review 42(1): 1-64.

Craig, Robin Kundis. 2018. "Water Quality Law in the US and EU: A Comparison of the Clean Water Act and Water Framework Directive.” EuropeNow, December 10.

Cremeans, John E., and Frank W. Segel. 1975, “National expenditures for pollution abatement and control, 1972.” Survey of Current Business 55: 8-11.

Cropper, Maureen L., and Wallace E. Oates. 1992. “Environmental Economics: A Survey.” Journal of Economic Literature 30(2): 675-740.

Cutler, David, and Grant Miller. 2005. “The role of public health improvements in health advances: The twentieth-century United States.” Demography 42(1): 1-22.

Diamond, Peter A., and Jerry A. Hausman. 1994. “Contingent Valuation: Is Some Number Better than No Number?” Journal of Economic Perspectives 8(4): 45-64.

Dingell, John D. 2010. “Preamble.” In John H. Hartig, Burning Rivers. Ontario, Canada: Ecovision.

Duflo, Esther, Michael Greenstone, Rohini Pande, and Nicholas Ryan. 2013. “Truth-telling by Third-party Auditors and the Response of Polluting Firms: Experimental Evidence from India.” Quarterly Journal of Economics 128(4): 1499-1545.

Earnhart, Dietrich. 2004. "Panel Data Analysis of Regulatory Factors Shaping Environmental Performance.” Review of Economics and Statistics 86(1): 391-401.

Ebenstein, Avi. 2012. "The Consequences of Industrialization: Evidence from Water Pollution and Digestive Cancers in China.” Review of Economics and Statistics 94(1): 186-201. 
Fisher-Vanden, Karen A., and Sheila M. Olmstead. 2013. "Moving pollution trading from air to water: potential, problems, and prognosis.” Journal of Economic Perspectives 27(1): 147-172.

Freeman, A. Myrick III. 2000. “Water Pollution Policy.” In Portney, Paul R., and Robert N. Stavins. Eds., Public Policies for Environmental Protection. Washington, DC: Resources for the Future, 169-213. Gallup. 2018. “Environment.” Accessed November 9, 2018. https://news.gallup.com/poll/1615/environment.aspx

Garg, Teevrat, Stuart E. Hamilton, Jacob P. Hochard, Evan Plous Kresch, and John Talbot. 2018. “(Not so) gently down the stream: River pollution and health in Indonesia.” Journal of Environmental Economics and Management 92(1): 35-53.

Glicksman, Robert L., and Dietrich H. Earnhart. 2007. “The Comparative Effectiveness of Government Interventions on Environmental Performance in the Chemical Industry.” Stanford Environmental Law Journal 26(2): 317-72.

Goodstein, Eban S. 2002. Economics and the Environment, 3rd Ed. New York: John Wiley \& Sons.

Gray, Wayne B., and Jay P. Shimshack. 2011. "The Effectiveness of Environmental Monitoring and Enforcement: A Review of the Empirical Evidence.” Review of Environmental Economics and Policy 5(1): 3-24.

Greenstone, Michael. 2003. “Estimating Regulation-Induced Substitution: The Effect of the Clean Air Act on Water and Ground Pollution.” American Economic Review Papers and Proceedings 93(2): 442448.

Griffiths, Charles, Heather Klemick, Matt Massey, Chris Moore, Steve Newbold, David Simpson, Patrick Walsh, and William Wheeler. 2012. “U.S. Environmental Protection Agency Valuation of Surface Water Quality Improvements.” Review of Environmental Economics and Policy 6(1): 130-146.

Grooms, Katherine K. 2016. “Does Water Quality Improve When a Safe Drinking Water Act Violation is Issued? A Study of the Effectiveness of the SDWA in California.” B.E. Journal of Economic Analysis and Policy 16(1): 1-23.

Gruber, Jonathan. 2011. Public Finance and Public Policy, 3rd Ed. New York: Worth Publishers. 
Hahn, Robert W. 2000. Reviving Regulatory Reform: A Global Perspective. Washington, DC: AEIBrookings Joint Center for Regulatory Studies.

Hausman, Jerry. 2012. “Contingent Valuation: From Dubious to Hopeless.” Journal of Economic Perspectives 26(4): 43-56.

He, Guojun, Shaoda Wang, and Bing Zhang. 2018. "Leveraging Political Incentives for Environmental Regulation: Evidence from Chinese Manufacturing Firms.” Mimeo, HKUST.

Helland, Eric. 1998. “The Enforcement of Pollution Control Laws: Inspections, Violations, and SelfReporting.” Review of Economics and Statistics 80(1): 141-153.

Keiser, David A., and Joseph S. Shapiro. 2019. “Consequences of the Clean Water Act and the Demand for Water Quality.” Quarterly Journal of Economics 134(1): 349-396.

Keiser, David A., Catherine L. Kling, and Joseph S. Shapiro. 2019. "The low but uncertain measured benefits of US water quality policy.” Proceedings of the National Academy of Sciences 116(12): 5262-5269.

Kling, Catherine L., Daniel J. Phaneuf, and Jinhua Zhao. 2012. "From Exxon to BP: Has Some Number Become Better than No Number?” Journal of Economic Perspectives 26(4): 3-26.

Kolstad, Charles D. 2011. Environmental Economics 2nd Ed. New York: Oxford University Press.

Laplante, Benoit, and Paul Rilstone. 1996. "Environmental Inspections and Emissions of the Pulp and Paper Industry in Quebec.” Journal of Environmental Economics and Management 31: 19-36.

Lee, Christine M., Tiffani Orne, and Blake Schaeffer. 2014. "How Can Remote Sensing Be Used for Water Quality Monitoring?” Presented at National Water Quality Monitoring Council $9^{\text {th }}$ National Monitoring Conference. Cincinnati, OH, April 28 - May 2. https://acwi.gov/monitoring/conference/2014/1ExtendedSessions/L8/Lee_RemoteSensingWorksh op.pdf , visited 11/28/2018.

Lipscomb, Molly, and Ahmed Mushfiq Mobarak. 2017. "Decentralization and Pollution Spillovers: Evidence from the Re-drawing of County Borders in Brazil.” Review of Economic Studies 84(1): 464-502. 
Magat, Wesley A., and W. Kip Viscusi. 1990. “Effectiveness of the EPA’s Regulatory Enforcement: The Case of Industrial Effluent Standards.” Journal of Law \& Economics 33(2): 331-360.

Malik, Arun S., Bruce A. Larson, and Marc Ribuado. 1994. "Economic Incentives for Agricultural Nonpoint Source Pollution Control” Water Resources Bulletin 30(3): 471-480.

Mason, Charles F., Lucija A. Muehlenbachs, and Sheila M. Olmstead. 2015. “The Economics of Shale Gas Development.” Annual Review of Resource Economics 7: 269-89.

Mehan III, G. Tracy. 2010. “A Symphonic Approach to Water Management: The Quest for New Models of Watershed Governance.” Journal of Land Use \& Environmental Law 26(1): 1-33.

Messner, Michael, Susan Shaw, Stig Regli, Ken Rotert, Valerie Blank, and Jeff Soller. 2006. “An approach for developing a national estimate of waterborne disease due to drinking water and a national estimate model application.” Journal of Water and Health 4(2): 201-240.

Milazzo, Paul Charles. 2006. Unlikely Environmentalists: Congress and Clean Water, 1945-1972. University Press of Kansas.

Muehlenbachs, Lucija, Elisheba Spiller, and Christopher Timmins. 2015. “The Housing Market Impacts of Share Gas Development.” American Economic Review 105(12): 3633-3659.

Nigra, Anne A., Tiffany R. Sanchez, Keeve E. Nachman, David E. Harvey, Steven N. Chillrud, Joseph H. Graziano, and Ana Navas-Acien. 2017. “The effect of the Environmental Protection Angecy maximum contaminant level on arsenic exposure in the USA from 2003 to 2014: an analysis of the National Health and Nutrition Examination Survey.” The Lancet 2(11): e513-e521.

NPS. 2018. “The Cuyahoga River.” Visited November 5, 2018.

https://www.nps.gov/cuva/learn/kidsyouth/the-cuyahoga-river.htm

Olmstead, Sheila M. 2010. “The economics of water quality.” Review of Environmental Economics and Policy 4(1): 44-62.

Olmstead, Sheila M., Lucija Muehlenbachs, Jhih-Shyang Shih, Ziyan Chu, and Alan Krupnick. 2013. "Shale gas development impacts on surface water quality in Pennsylvania.” Proceedings of the National Academy of Sciences 110(13): 4962-4967. 
Parris, Kevin. 2011. "Impact of Agriculture on Water Pollution in OECD Countries: Recent Trends and Future Prospects.” International Journal of Water Resources Development 27(1): 33-52.

Phaneuf, Daniel J., and Till Requate. 2017. A Course in Environmental Economics: Theory, Policy, and Practice. New York: Cambridge University Press

Raucher, Robert S. 1996. "Public Health and Regulatory Considerations of the Safe Drinking Water Act.” Annual Reviews of Public Health 17: 179-202.

Read, Emily K., Lindsay Carr, Laura De Cicco, Hilary A. Dugan, Paul C. Hanson, Julia A. Hart, James Kreft, Jordan S. Read, and Luke A. Winslow. 2017. "Water quality data for national-scale aquatic research: The Water Quality Portal.” Water Resources Research 53(2): 1735-1745.

Roback, Jennifer. 1982. “Wages, Rents, and the Quality of Life.” Journal of Political Economy 90(6): 12571278.

Rosen, Harvey S. 2002. Public Finance 6th Ed. Boston, MA: McGraw-Hill Irwin

Russi, Daniela, and Andrew Farmer. 2018. "Testing a methodology to assess the costs and benefits of the implementation of the EU water acquis in selected river basins.” Technical report, Institute for European Environmental Policy.

SciLine. 2019. "Lead in U.S. Drinking Water. https://www.sciline.org/evidence-blog/lead-drinking-water Visited 6/2/2019.

Shapiro, Joseph S., and Reed Walker. 2018. "Why is Pollution from US Manufacturing Declining? The Roles of Environmental Regulation, Productivity, and Trade.” American Economic Review 108(12): 3814-54.

Shimshack, Jay P. and Michael B. Ward. 2008. “Enforcement and over-compliance.” Journal of Environmental Economics and Management 55(1): 90-105.

Sigman, Hilary. 2002. “International Spillovers and Water Quality in Rivers: Do Countries Free Ride?” American Economic Review: Papers and Proceedings 92(4): 1152-1159.

Smith, Richard A., Richard B. Alexander, and M. Gordon Wolman. 1987. "Water-Quality Trends in the Nation’s Rivers.” Science 235(4796): 1607-1615. 
Smith, V. Kerry, and Carlos Valcarcel Wolloh. 20122. "Has Surface Water Quality Improved Since the Clean Water Act?” NBER Working Paper No. 18192.

Snow, John. 1855. On the Mode of Communication of Cholera. London: John Churchill.

Stigler, George. 1952. The Theory of Price. New York: Macmillan.

Stigler, George. 1966. The Theory of Price. New York: Macmillan.

Sullivan, Patrick J., Franklin J. Agardy, and James J. J. Clark. 2005. The Environmental Science of Drinking Water. New York: Elsevier.

Tiemann, Mary. 2017. "Safe Drinking Water Act (SDWA): A Summary of the Act and Its Major Requirements.” Washington, DC: Congressional Research Service.

Time Magazine. 1969. “The Cities: The Price of Optimism.” August 1.

U.S. Census Bureau. 1971. “1967 Census of Manufactures: Water Use in Manufacturing.” Washington, DC: U.S. Census Bureau.

U.S. Census Bureau. 1986. “1982 Census of Manufactures: Water Use in Manufacturing” Washington, DC: U.S. Census Bureau.

USDA. 2018. “Watershed Boundary Dataset (WBD) Facts.” Visited 11/27/2018.

https://www.nrcs.usda.gov/wps/portal/nrcs/detail/national/water/watersheds/dataset/?cid=nrcs143 $\underline{021617 .}$

USEPA. 1972. “Industrial Pollution of the Lower Mississippi River in Louisiana.” Washington, DC: USEPA.

USEPA. 1999. “25 Years of the Safe Drinking Water Act: History and Trends.” Washington, DC: USEPA. USEPA. 2000a. “A Benefits Assessment of Water Pollution Control Programs Since 1972: Part 1, The Benefits of Point Source Controls for Conventional Pollutants in Rivers and Streams: Final Report.” Technical Report.

USEPA. 2000b. "Progress in Water Quality: An Evaluation of the National Investment in Municipal Wastewater Treatment.” Washington, DC: USEPA.

USEPA. 2010. “NPDES Permit Writers’ Manual.” Washington, DC: USEPA. 
USEPA. 2015. "Regulation Timeline: Contaminants Regulated Under the Safe Drinking Water Act.” Mimeo, September 2015. Accessed November 28, 2018. https://www.epa.gov/sites/production/files/2015-10/documents/dw_regulation_timeline.pdf

USEPA. 2018a. “ATTAINS, National Summary of State Information.” Accessed November 8, 2018. https://ofmpub.epa.gov/waters10/attains nation_cy.control.

USEPA. 2018b. “National Primary Drinking Water Regulations.” Visited November 28, 2018. https://www.epa.gov/sites/production/files/2016-06/documents/npwdr_complete_table.pdf

USEPA. 2019. “TSCA Chemical Substance Inventory.” https://www.epa.gov/tsca-inventory/how-accesstsca-inventory. Visited June 12, 2019

USPHS. 1970. “Community Water Supply Study: Analysis of National Survey Findings.” USPHS.

Wrenn, Douglas H., Allen Klaiber, and Edward C. Jaenicke. 2016. "Unconventional Shale Gas Development, Risk Perceptions, and Averting Behavior: Evidence from Bottled Water Purchases.” Journal of the Association of Environmental and Resource Economists 3(4): 779-817. 
Figure 1

Share of Americans Concerned “A Great Deal” about Various Environmental Issues, 1989-2018

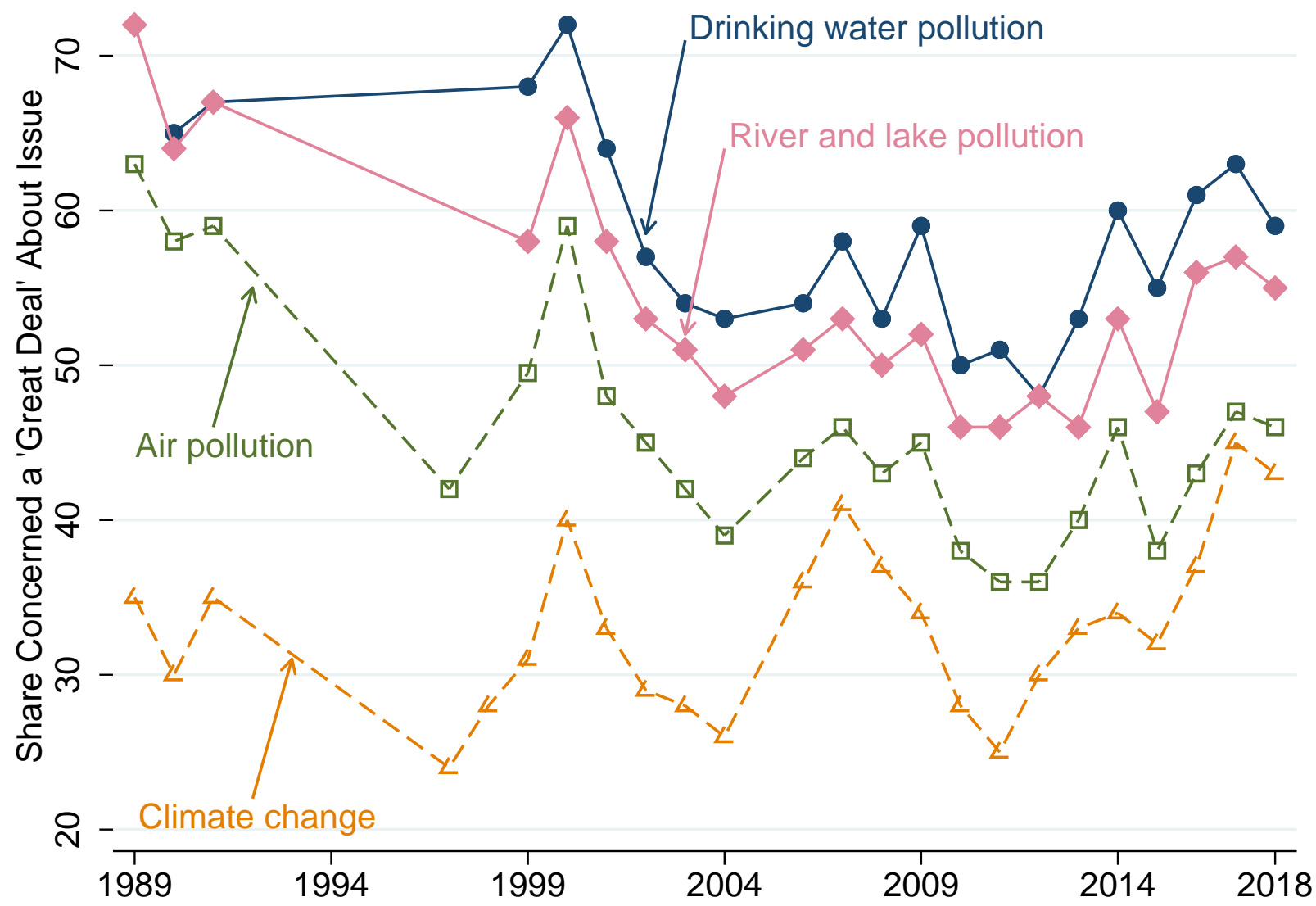

Source: Gallup (2018). Each poll asks, “I’m going to read you a list of environmental problems. As I read each one, please tell me if you personally worry about this problem a great deal, a fair amount, only a little or not at all.” The graph shows four issues to avoid too many lines obscuring the main patterns. Results for other issues, which are not surveyed in all years, include the following: loss of tropical rain forests (mean share 40 percent), extinction of plant and animal species (38 percent), contamination of soil and water by toxic waste (54 percent), damage to Earth's ozone layer (42 percent), acid rain (28 percent), loss of natural habitat for wildlife (51 percent), ocean and beach pollution (51 percent), maintenance of the nation's fresh water for household needs (48 percent), and contamination of soil and water by radioactivity from nuclear facilities (49 percent). Stated concern about drinking water and also river and lake pollution equals or exceeds stated concern about each of these other issues in nearly every year of the survey. 
Figure 2

U.S. Surface Water Pollution, 1972-2014



Note: Graph shows year fixed effects plus a constant from regressions that also control for monitoring site fixed effects, a day-of-year cubic polynomial, and an hour-of-day cubic polynomial. Each observation in the regression is an individual pollution reading at a specific monitoring site; the dependent variable in the regression takes the value one if it violates the fishable standard and zero otherwise. Connected dots show yearly values, dashed lines show 95 percent confidence interval, and 1972 is the reference category. Standard errors clustered by watershed. Graph summarizes 14.6 million pollution readings from 265,000 monitoring sites from Storet Legacy, Modern Storet, and the National Water Information System. See Keiser and Shapiro (2019) for details on the data cleaning procedure. 
Figure 3

U.S. Drinking Water Quality Violations, 1982-2014

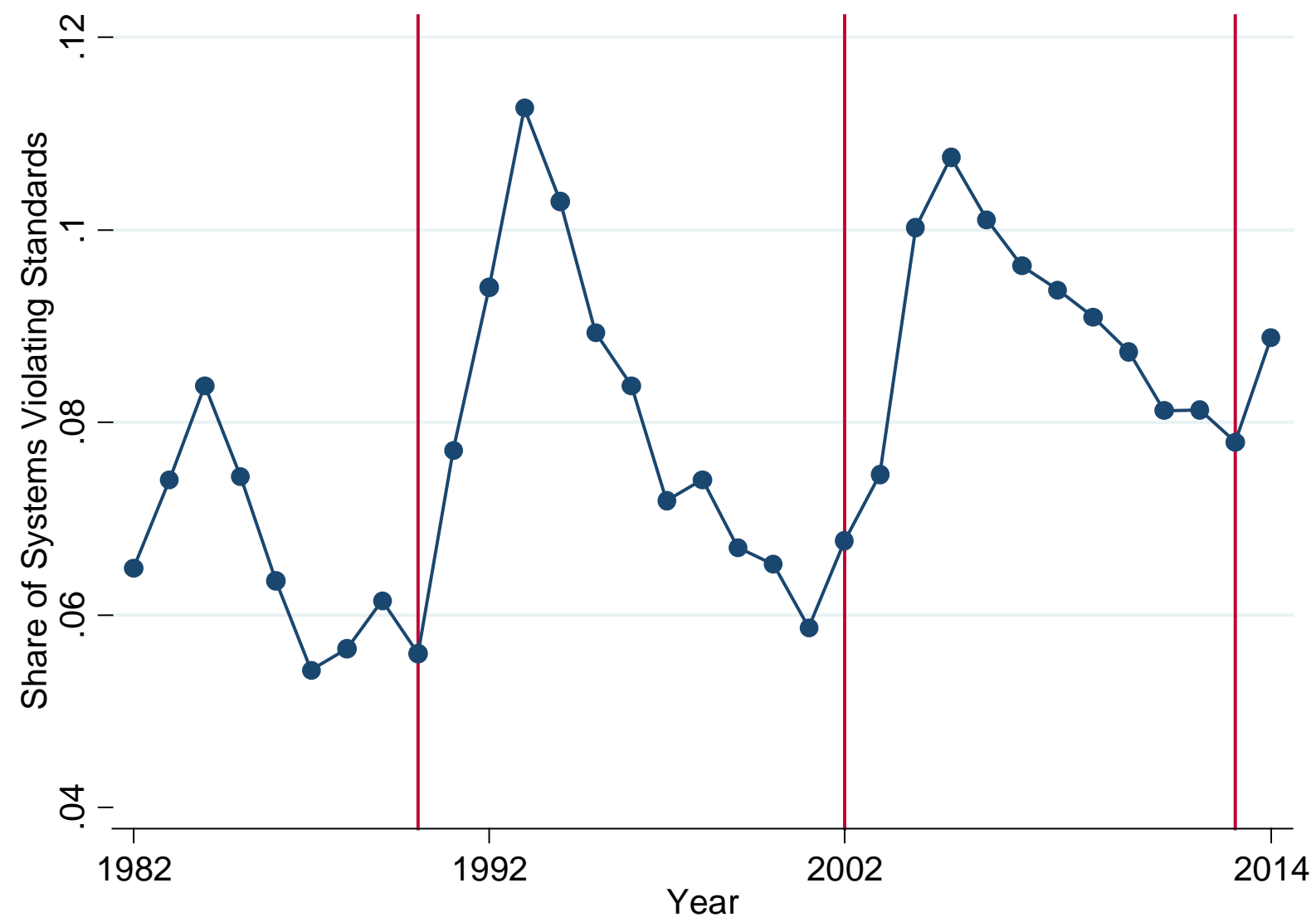

Note: Data from Allaire (2018) and cover a balanced panel of 17,900 community water systems. Vertical lines show years of the most important changes in standards (Total Coliform Rule in 1990, Stage 1 Drinking Water Byproducts rule in 2002, and Stage 2 Drinking Water Byproducts rule in 2013). Each point shows the share of community water systems violating health-based standards. 
Figure 4

Annual Investments to Clean Pollution in Surface Waters, Drinking Water, and Air, 1970-2010
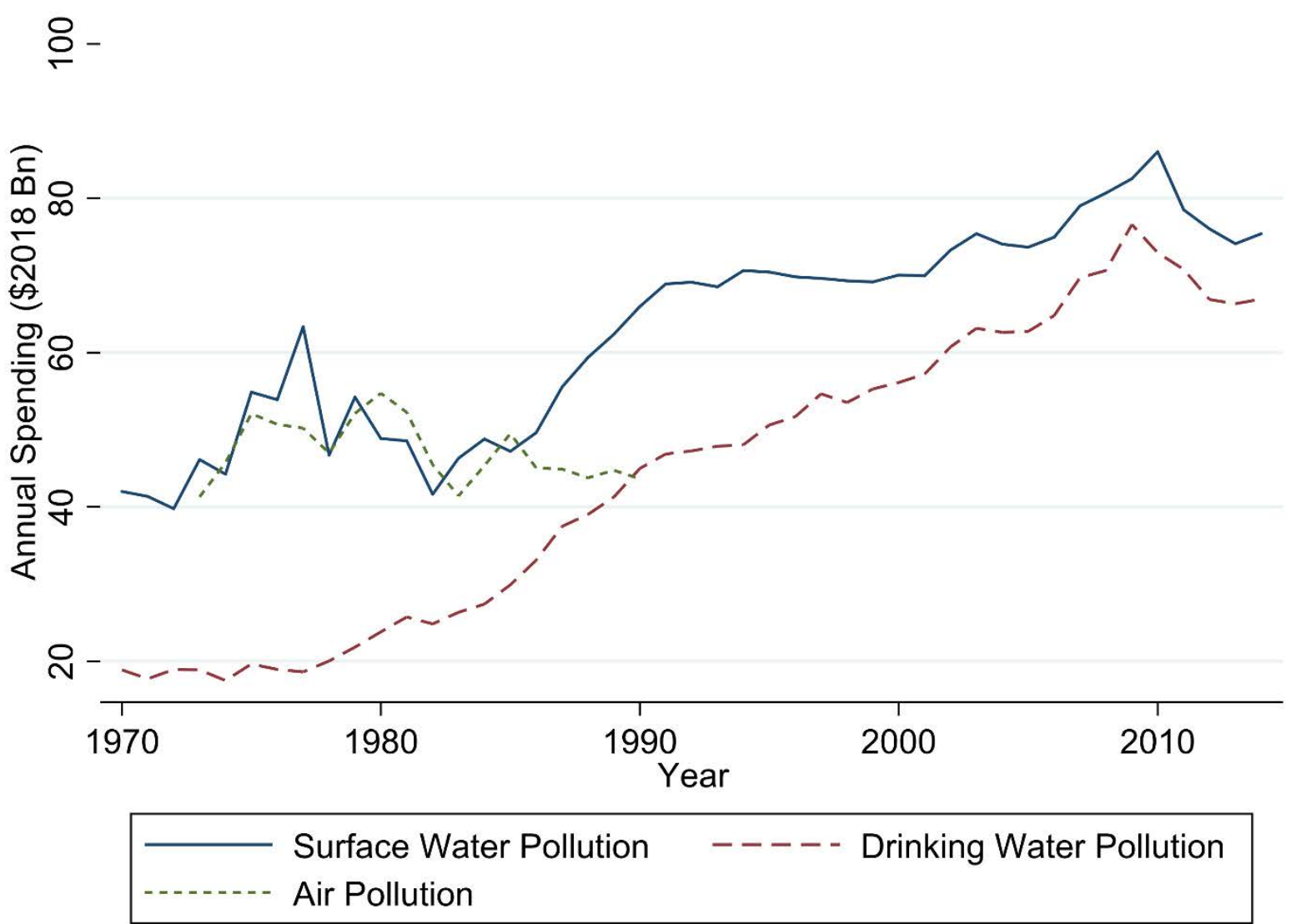

Note: See sources and details in Appendix A. Expenditures include public and private sources, industry, agriculture, transportation (e.g., catalytic converters and reformulated gasoline), and all other sources with available data. Air pollution line only shows annual values for 1973 to 1990 since these are the years with the most reliable data; available air pollution expenditure estimates for other individual years require more imputation. All values deflated to \$2017 using the Engineering News Record Construction Price Index. 
Table 1.

Benefits and Costs of Federal Regulations

\begin{tabular}{|c|c|c|c|c|c|c|}
\hline & $\begin{array}{c}\text { Surface } \\
\text { Water } \\
(1)\end{array}$ & $\begin{array}{c}\text { Drinking } \\
\text { Water } \\
(2) \\
\end{array}$ & $\begin{array}{l}\text { Air } \\
(3) \\
\end{array}$ & $\begin{array}{c}\text { reenhou } \\
\text { Gases } \\
(4) \\
\end{array}$ & $\begin{array}{c}\text { All Other } \\
\text { (5) }\end{array}$ & $\begin{array}{l}\text { All } \\
(6) \\
\end{array}$ \\
\hline \multicolumn{7}{|c|}{ Panel A. Total U.S. Expenditures (\$2017 trillion) } \\
\hline 1970 to 2014 & $\$ 2.83$ & $\$ 1.99$ & $\$ 2.11$ & - & - & - \\
\hline 1973 to 1990 & $\$ 0.94$ & $\$ 0.49$ & $\$ 0.85$ & - & - & - \\
\hline \multicolumn{7}{|c|}{ Panel B. Estimated Benefits and Costs of Regulations Analyzed in Years 1992-2017 } \\
\hline Total: Benefits / Total Costs & 0.79 & 4.75 & 12.36 & 2.98 & 1.97 & 6.31 \\
\hline Mean Benefits / Mean Costs & 0.57 & 8.26 & 15.18 & 3.64 & 21.79 & 16.17 \\
\hline Share With Benefits < Costs & 0.67 & 0.20 & 0.08 & 0.00 & 0.19 & 0.15 \\
\hline
\end{tabular}

Note: Column (5) covers all regulations not in columns (1)-(4). For years after 2004, data are from Table A-1 of the "Report to Congress on the Benefits and Costs of Federal Regulations and Unfunded Mandates on State, Local, and Tribal Entities.” For earlier years, data are from various tables of predecessor reports. For studies which estimate a lower bound and upper bound on costs or benefits, this table averages the two. When costs or benefits are estimated for multiple discount rates, this table uses values for a 3 percent discount rate. When studies present multiple estimates for other reasons, this table averages the multiple estimates. Table includes the few studies which report negative costs (that is, cost savings). It also includes studies which contain notes that their benefits or costs are incomplete in specific known ways. This table excludes regulations with unreported benefits or unreported costs, or regulations with benefits and costs not reported in monetary terms, or in non-comparable monetary terms. Greenhouse gases includes energy efficiency regulations. For studies listing only a bound (for example, benefits up to $\$ 10$ million), this table uses the bound. Regulations affecting emissions from all media (as an example, regulating manufacture and disposal of PCBs) are not listed as air or water policies. Total US Expenditures reflect public and private investments (see Appendix A), and are not readily available for greenhouse gases or all other regulations (columns 4-5). 


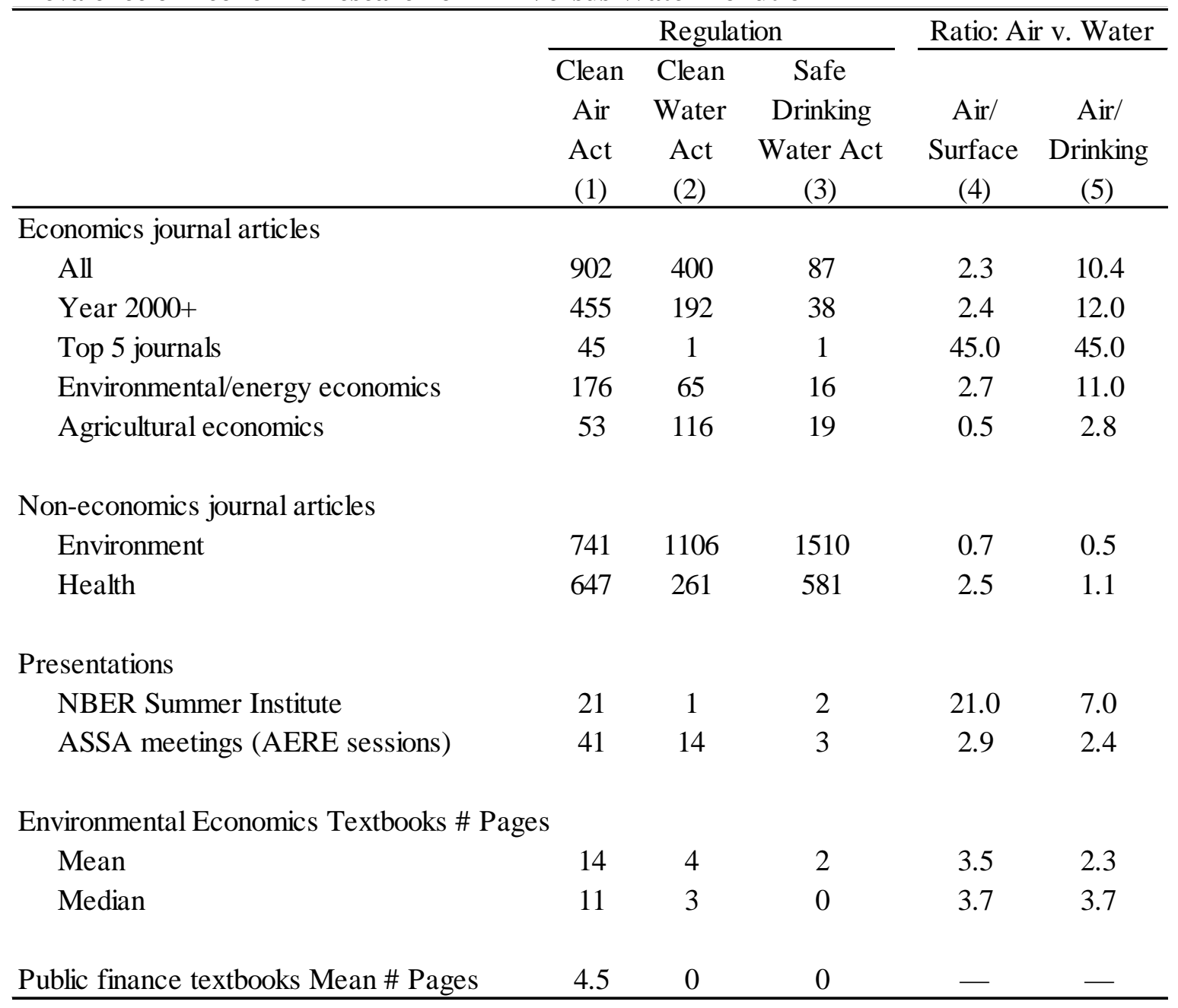

Note: All journal articles are from JSTOR. Environmental textbooks include Chapman (2000), Goodstein (2002), Berck and Helfand (2011), Kolstad (2011), Callan and Thomas (2013), Anderson and Libecap (2014), Freeman, Herriges, and Kling (2014), Phaneuf and Requate (2017), and Tietenberg and Lewis (2018). Public finance textbooks include Rosen (2002) and Gruber (2011). The NBER data cover 20092018 environmental/energy economics sessions, while the ASSA data cover years 2011-2019. The ASSA papers include all those in sessions contributed by the Association of Environmental and Resource Economists (AERE). See Appendix B for additional details. 


\section{Appendix Figures and Tables}

\section{Appendix Figure 1}

U.S. Surface Water Pollution Trends, 1972-2014, Additional Pollutants

Panel A. Biochemical Oxygen Demand

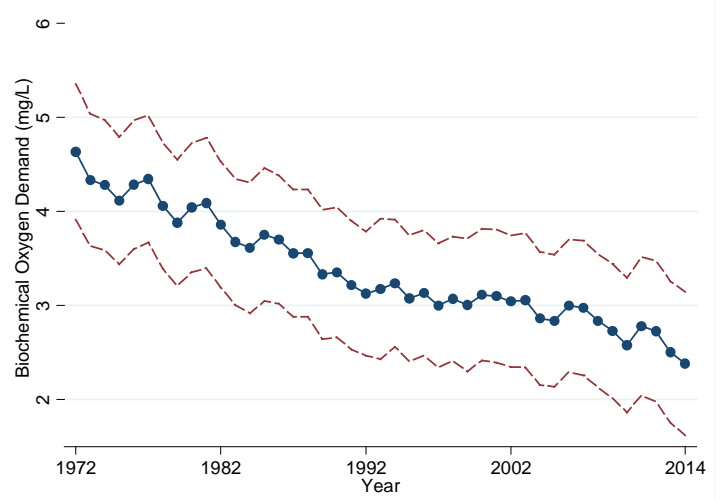

Panel C. Fecal Coliforms

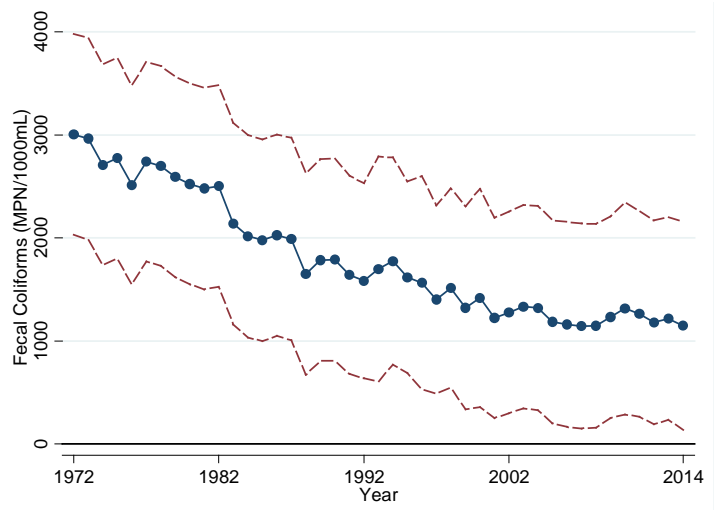

Note: see notes to Figure 2.
Panel B. Dissolved Oxygen Saturation Deficit

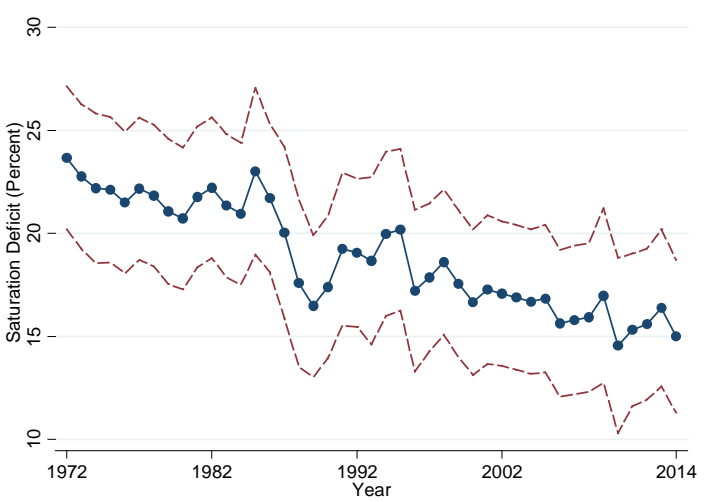

Panel D. Total Suspended Solids

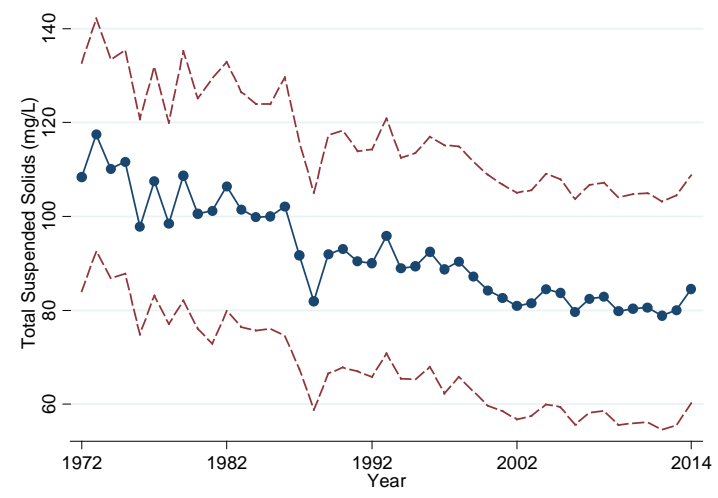




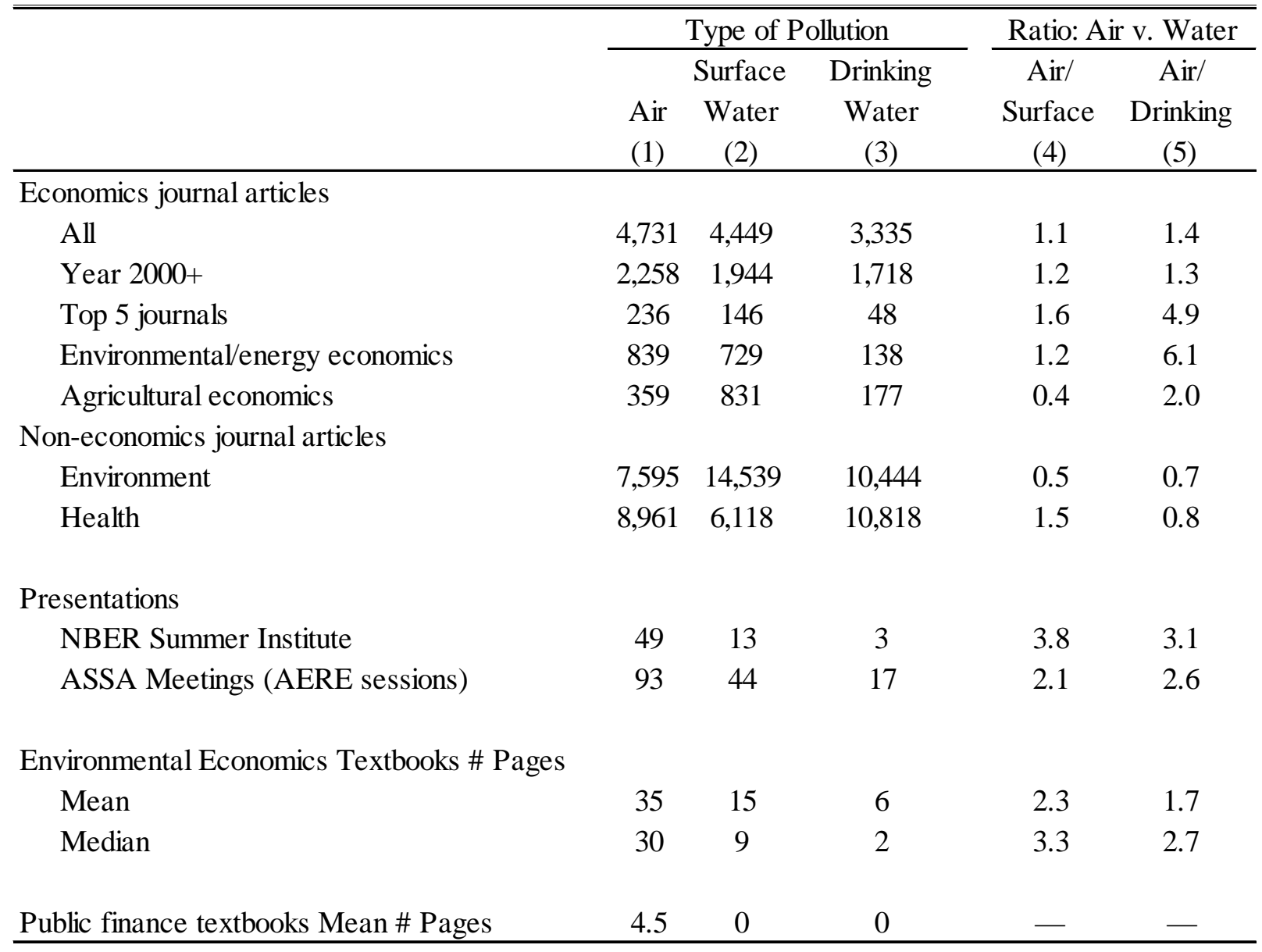

Note: All journal articles are from JSTOR. Environmental textbooks include Chapman (2000), Goodstein (2002), Berck and Helfand (2011), Kolstad (2011), Callan and Thomas (2013), Anderson and Libecap (2014), Freeman, Herriges, and Kling (2014), Phaneuf and Requate (2017), and Tietenberg and Lewis (2018). Public finance textbooks include Rosen (2002) and Gruber (2011). The NBER data cover 20092018 environmental/energy economics sessions, while the ASSA data cover years 2011-2019. The ASSA papers include all those in sessions contributed by the Association of Environmental and Resource Economists (AERE). See Appendix B for additional details. 


\section{Appendix A: Estimates of Spending on Air and Water Pollution Control Programs}

This appendix describes available data on the total costs of investments in surface water quality, drinking water, and air pollution abatement. We construct estimates of spending using a number of sources. These include Keiser and Shapiro’s (2019) analysis of the Clean Water Act municipal grants program, Keiser, Kling, and Shapiro's (2019) analysis of benefits and costs of surface water quality programs, a Congressional Research Service report on federal appropriations of surface and drinking water programs at USEPA (Copeland 2015), a Congressional Budget Office (2018) report on public spending on transportation and water infrastructure, and a report on local spending on water and wastewater services from the U.S. Conference of Mayors (2010). We also use a number of reports by USEPA detailing costs of the Clean Air Act and Keiser and Shapiro's (2019) analysis of spending on air pollution control programs. Obtaining comprehensive spending estimates in each of these areas faces a number of challenges including incomplete reporting across communities and across time and the potential for double counting of federal, state, and local spending.

This Appendix reports a range of estimates; the main text highlights the best available estimates. We also focus on the period 1970 to 2014 since spending estimates for each of these categories are more complete for this period. We deflate all estimates to \$2017 using the Engineering NewsRecord Construction Cost Index.

\section{Surface Water Quality - Preferred Estimate: \$2.8 trillion (range of \$1.9 to \$3.0 trillion)}

Keiser and Shapiro (2019) and Keiser, Kling, and Shapiro (2019) report estimates of spending on surface water quality pollution control programs that are driven primarily by federal policies (i.e, the Clean Water Act's municipal grants program and the Clean Water Act's State Revolving Funds program), industrial spending on water pollution abatement, and non-point source programs sponsored by the federal government such as a number of U.S. Department of Agriculture conservation programs.

Federal Spending - Preferred Estimate: \$0.6 trillion (range of \$0.5 to \$0.6 trillion)

To account for federal government funds, we use Keiser and Shapiro's (2019) estimate of spending on grants to local municipalities and net out local matching expenditures on capital, operations, and maintenance costs. We add spending estimates on the federal portion of Clean Water State Revolving Funds (CWSRFs) from Keiser, Kling, and Shapiro (2019). These sources suggest approximately $\$ 370$ billion in direct federal spending on wastewater treatment. This estimate exceeds Copeland's (2015) estimate of \$256 billion in total appropriations for wastewater treatment programs, though Copeland’s estimates start in 1973. This estimate also exceeds CBO’s (2018) estimate of total federal spending on both wastewater and drinking water treatment (\$363 billion). However, Copeland's federal appropriation estimates for drinking water only total \$26 billion, which suggests CBO's total estimate is likely largely due to wastewater treatment. Each source suggests similar patterns in funding over time, with much greater amounts in the 1970s. We use the estimates from Keiser and Shapiro (2019) as they reflect estimates of grant spending recovered from USEPA records and Clean Water State Revolving Funds estimates from USEPA. 
In addition to these funds, we include spending on non-point source control programs from Keiser, Kling, and Shapiro (2019) that primarily reflect spending on USDA conservation programs. This adds an additional $\$ 219$ billion. Our preferred estimates for total federal spending on wastewater treatment is thus $\$ 589$ billion with a range of $\$ 475$ billion to $\$ 589$ billion.

\section{Local Spending - Preferred Estimate: \$1.6 trillion (range of \$0.8 to 1.7 trillion)}

Our estimates of local spending on wastewater treatment comes from CBO (2018) and the U.S. Conference of Mayors (2010). We first take annual spending estimates from CBO (2018) that represent state and local spending for infrastructure, net of federal grant and loan subsidies. These estimates represent both wastewater and drinking water spending. To apportion this spending between wastewater and drinking water, we use the U.S. Conference of Mayors (2010) report that provides estimates of the share of local spending by decade between wastewater and drinking water treatment. The CBO (2018) and U.S. Conference of Mayors (2010) estimates of total spending on wastewater and drinking water treatment track each other closely and are based on similar census data. However, the U.S. Conference of Mayors local spending estimates may also reflect federal grants and subsidies. For example, CBO's estimates of federal contributions to wastewater and drinking water total \$363 billion. This figure added to CBO’s estimate of \$3.6 trillion in state and local spending net of federal spending closely approximates the U.S. Conference of Mayors (2010) estimate (\$3.92 vs. \$3.87 trillion).

Keiser, Kling, and Shapiro (2019) present estimates of local spending tied to federal and state programs (i.e., the Clean Water Act grants and CWSRF). These estimates are broadly similar through 1986 (\$251 billion for Keiser, Kling, and Shapiro vs. \$348 billion for CBO and the Conference of Mayor estimates). The main divergences occur after 1986, corresponding to a sharp decline in the federal grants program. Since Keiser, Kling, and Shapiro focus on spending tied to federal programs while CBO includes local spending independent of federal grants, the CBO estimate is likely to be more complete.

Our preferred estimate of local spending is thus $\$ 1.6$ trillion with a range of $\$ 801$ billion to $\$ 1.7$ trillion. The Keiser and Shapiro (2019) local estimate reflects our lower bound and the U.S. Conference of Mayors (2010) report reflects our upper bound.

Industrial - Preferred Estimate: \$0.6 trillion

Our estimates of industrial spending are based on Keiser and Shapiro (2019) and Keiser, Kling, and Shapiro (2019). These estimates are based on Pollution Abatement Costs and Expenditures (PACE) surveys from 1973 - 1986, 1988 - 1994, and 2005.

\section{Drinking Water Quality - Preferred Estimate: \$2.0 trillion (range of \$2.0 to \$2.2 trillion)}

Federal Spending - Preferred Estimate: \$26B

We use Copeland's (2015) estimate of federal appropriations for Drinking Water State Revolving Funds, which started in 1997. These total \$26B.

Local and State Spending - Preferred Estimate: \$1.9 trillion (range of \$1.9 to \$2.1 trillion) 
To estimate local and state spending, we follow a similar protocol for drinking water as for wastewater. We allocate CBO's (2018) estimate of total local spending net of federal contributions based on the U.S. Conference of Mayors (2010) estimate of the share of spending assigned to wastewater versus drinking water. This yields an estimate of \$1.9 trillion in local and state spending on drinking water treatment. The U.S. Conference of Mayors (2010) estimates provide a slightly larger figure at \$2.1 trillion.

\section{Air Pollution Control - Preferred Estimate: \$2.1 trillion (range of \$2.1 to 2.7 trillion)}

We use EPA's (1997) retrospective analysis of the Clean Air Act as the main source for expenditures on air pollution control. These expenditures represent additional spending due to the Clean Air Act. We do not observe expenditures from before the Clean Air Act, so these estimates may provide a lower bound on total spending. EPA (1997) estimates annual expenditures on compliance costs for 1973 to 1990 . For 1970 to 1972, we assume annual expenditures equal expenditures in 1973. While expenditures in 1973 were the lowest of any year, expenditures in real dollars remained fairly steady over this time period (\$41.3B in 1973 versus an average of \$47.2B per year for 1973 to 1990 ).

Recovering annual estimates after 1991 is more challenging. Table 1 assumes that annual estimates for 1991 to 2014 equal the average expenditures from 1973 to 1990. This is a strong assumption, since the Clean Air Act Amendments of 1990 may have increased spending. However, a separate prospective study by USEPA for 1990 to 2020 (USEPA 2011) provide similar estimates of total spending over this time period. For example, our cost estimates for 2000 to 2014 are $\$ 708$ billion, which is roughly similar to estimates of $\$ 877$ billion from EPA. We construct an upper range estimate given a few of these sources. First, we use EPA's restrospective estimates until 1988. We then assume a jump in costs due to the CAAA that correspond to an increase we observe in the PACE data through 1994. We then assume constant cost estimates constant for 1995 to 2000. For 2001 to 2014, we assume costs increase by the same level of changes as in USEPA (2011). This procedure requires substantial imputation and interpolation, which is why Table 1 separately reports estimates for years where such imputation is not needed. This yields an upper bound estimate of $\$ 2.7$ trillion.

Keiser and Shapiro (2019) discuss an additional source of estimates from the Bureau of Economic Analysis for the years 1972 to 1994. These estimates place expenditures on air pollution abatement

at $\$ 1.1$ to $\$ 1.6$ trillion. Our estimates using the EPA retrospective analysis provide similar estimates over this time period of $\$ 1$ trillion. 


\section{Appendix B: Methodology for Counting References}

This appendix describes methods used to construct Table 2 and Appendix Table 1. Categories in these tables are defined as follows:

- “Top 5 economics” includes the American Economic Review (excluding Papers and Proceedings issues); Econometrica; Journal of Political Economy; Quarterly Journal of Economics; and Review of Economic Studies.

- "Environmental/energy economics" includes Climate Change Economics; Economics of Energy \& Environmental Policy; The Energy Journal; Environment and Development Economics; the Journal of Energy and Development; the Journal of the Association of Environmental and Resource Economists; Land Economics; and Marine Resource Economics.

- "Agricultural economics" includes the American Journal of Agricultural Economics; Choices; and the Journal of Agricultural and Resource Economics.

- "Non-economics: environment" includes all journals that JSTOR categorizes into environmental science or environmental studies.

- "Non-economics: health" includes all journals that JSTOR categorizes in health policy, health sciences, or public health, excluding the Journal of the American Water Works Association since it is the only journal in these categories not primary focused on health.

- "NBER Summer Institute” includes Environmental and Energy Economics (EEE) sessions, excluding 5-minute ("egg timer") presentations and excluding mentions of phrases in the bibliography. For papers not linked on NBER's site, we searched to find the closest version of the paper to the NBER conference date. For a few papers we could not find in any form (including under other titles or versions), we guessed the paper's content based on our direct knowledge of the paper or its title.

Journal articles are all from JSTOR and include "all content," limited to "articles" (i.e., excluding reviews, books, reports, pamphlets, or miscellaneous), searched Feb 26-28, 2019. For JSTOR broad categories (economics, environmental, etc.), we click individually on each journal in a category rather than the entire category, since individually selecting each journal lists additional articles.

A few journal classifications are worth explaining. We include the Journal of Agricultural and Resource Economics in "Agricultural Economics" since it emphasizes those topics and is published by the Western Agricultural Economics Association. We include Land Economics in "Environmental/energy economics" although a nontrivial share of its articles address agriculture. We exclude the Journal of the American Water Works Association from "Non-economics: health" since it is the only journal in this category not primarily focused on health. JSTOR also separately lists this journal in "Environmental Science," where we count it. The Journal of Environmental Economics and Management is not indexed in JSTOR, though Kube et al. (2017) review 40 years of its articles and find 52 articles on air pollution and 28 articles on water pollution (they do not distinguish articles on regulation from more general articles on pollution). 
Columns 2 and 3 of Table 2 also include articles mentioning "Federal Water Pollution Control Act." In textbooks, for air pollution, we counted page mentions in the index of topics starting with the phrases "CAA or "Clean Air Act." For water pollution, we counted page mentions starting with the phrases "Clean Water Act," "CWA," "Federal Water Pollution Control Act," or "FWPCA," "Safe Drinking Water Act,” or "SDWA.” In JSTOR, we did not include the acronyms "CAA," "FWPCA," or "SDWA," since these could represent unrelated phrases.

We obtained lists of National Bureau of Economic Research Summer Institute presentations from the NBER website, and lists of presentations at the Allied Social Science Association meetings from its website. The NBER data cover 2009-2018, while the ASSA data cover years 2011-2019. The ASSA papers include all those in sessions contributed by the Association of Environmental and Resource Economists (AERE). The ASSA data begin in 2011 since earlier years' AERE sessions are less readily distinguished. When possible, we use versions of these papers from the ASSA and AERE websites. When they are unavailable or links are broken, we use versions of the papers posted on the internet, and prefer paper versions from close to the year of the conference presentation. For cases where these approaches do not find the paper, we guess the content based on our direct knowledge of the paper or on its title.

Appendix Table 1 includes searches for use of the following phrases:

- Air pollution: clean air; air pollution; air quality; air pollutants;

- Surface water pollution: clean water; federal water; water quality; water pollution

- Drinking water pollution: drinking water

These also cover the regulations since, for example, the phrase "clean air" also includes use of the phrase "Clean Air Act.” For NBER and ASSA presentations, we exclude mention of these phrases in the bibliography.

\section{Bibliography}

Anderson, Terry L., and Gary D. Libecap. 2014. Environmental Markets: A Property Rights Approach. New York: Cambridge University Press.

Berck, Peter, and Gloria Helfand. 2011. The Economics of the Environment. Boston, MA: AddisonWesley.

Callan, Scott J., and Janet M. Thomas. 2013. Environmental Economics \& Management: Theory, Policy, and Applications. Mason, $\mathrm{OH}$ : South-Western.

Chapman, Duane, 2000. Environmental Economics: Theory, Application, and Policy. Reading, MA: Addison-Wesley.

Congressional Budget Office. 2018. "Public Spending on Transportation and Water Infrastructure, 1956 to 2017.” Visited November 20, 2018. https://www.cbo.gov/publication/54539,

Copeland, Claudia. 2015. "Funding for EPA Water Infrastructure: A Fact Sheet.” Congressional Research Service.

Freeman, A. Myrick III, Joseph A. Herriges, and Catherine L. Kling. 2014. The Measurement of Environmental and Resource Values; Theory and Methods. 3rd Ed. New York: RFF.

Goodstein, Eban S. 2002. Economics and the Environment, 3rd Ed. New York: John Wiley \& Sons.

Gruber, Jonathan. 2011. Public Finance and Public Policy, 3rd Ed. New York: Worth Publishers. 
Keiser, David A., and Joseph S. Shapiro. 2019. "Consequences of the Clean Water Act and the Demand for Water Quality.” Quarterly Journal of Economics 134(1): 349-396.

Keiser, David A., Catherine L. Kling, and Joseph S. Shapiro. 2019. "The low but uncertain measured benefits of US water quality policy.” Proceedings of the National Academy of Sciences 116(12): 5262-5269.

Kolstad, Charles D. 2011. Environmental Economics 2nd Ed. New York: Oxford University Press.

Kube, Roland, Andreas Löschel, , Henrik Mertens, and Till Requate. 2017. "40 Years of JEEM: Research Trends and Influential Publications in Environmental and Resource Economics.” CAWM Discussion $\quad$ Paper, $95 . \quad$ Online at https://www.wiwi.unimuenster.de/ceres/en/publications/128926.Phaneuf, Daniel J., and Till Requate. 2017. A Course in Environmental Economics: Theory, Policy, and Practice. New York: Cambridge University Press

Rosen, Harvey S. 2002. Public Finance 6th Ed. Boston, MA: McGraw-Hill Irwin

The U.S. Conference of Mayors - Mayors Water Council. 2010. "Trends in Local Government Expenditures on Public Water and Wastewater Services and Infrastructure: Past, Present, and Future."

USEPA. 1997. "The Benefits and Costs of the Clean Air Act, 1970 to 1990." https://www.epa.gov/sites/production/files/2015-06/documents/contsetc.pdf

USEPA. 2011. "Direct Cost Estimates for the Clean Air Act Second Section 812 Prospective Analysis.” https://www.epa.gov/sites/production/files/2015-07/documents/costfullreport.pdf 